
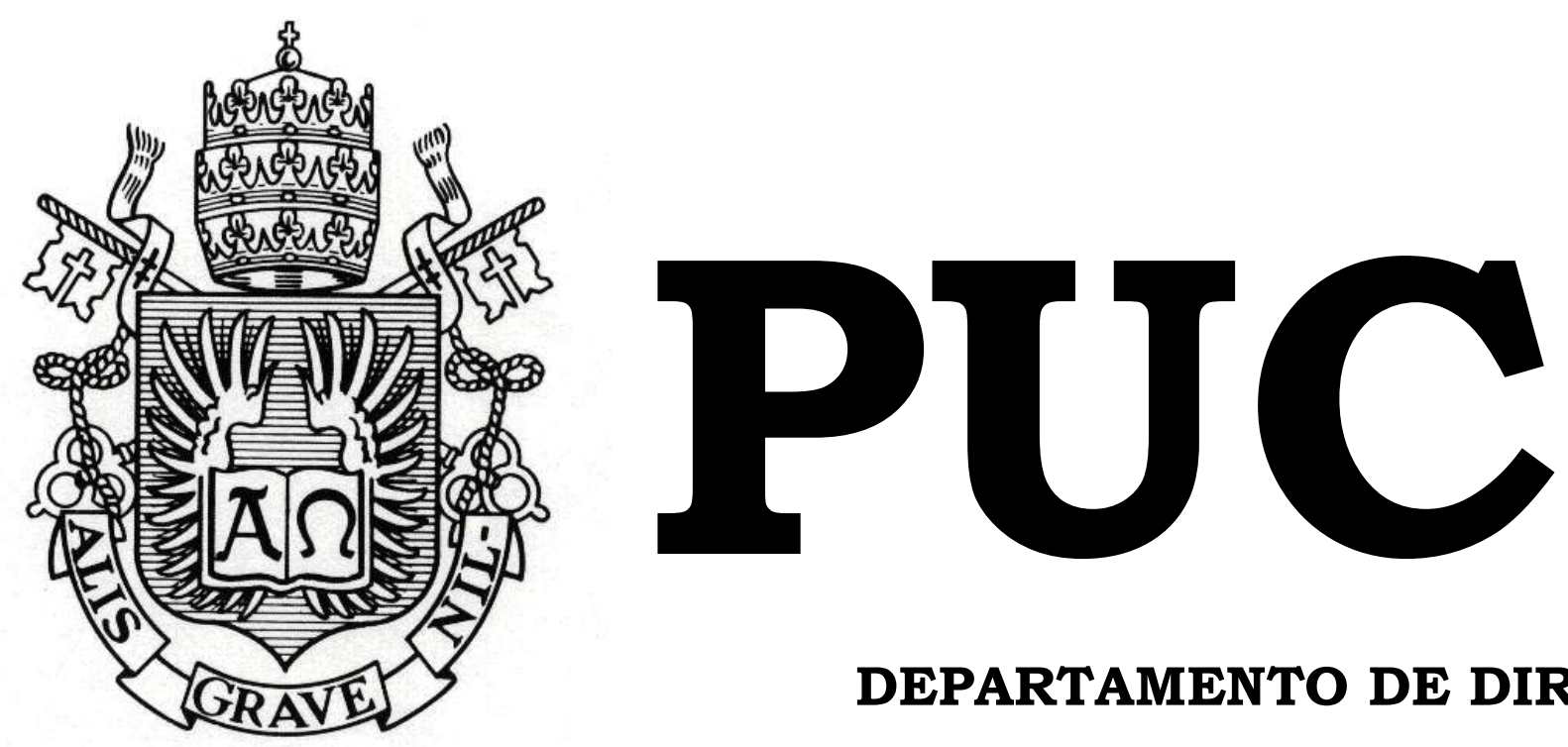

DEPARTAMENTO DE DIREITO

\title{
FILHOS SÓ DA MÃE? \\ O cabimento de danos morais por abandono afetivo paterno
}

por

Ana Luiza de Souza Billoria Alves

ORIENTADOR(A): Profa. Inês Alegria Rocumback 2012.2

PONTIFÍCIA UNIVERSIDADE CATÓLICA DO RIO DE JANEIRO RUA MARQUÊS DE SÃO VICENTE, 225 - CEP 22453-900 RIO DE JANEIRO - BRASIL 


\title{
FILHOS SÓ DA MÃE? \\ $O$ cabimento de danos morais por abandono afetivo paterno
}

\author{
por
}

ANA LUIZA DE SOUZA BILLORIA ALVES

Monografia

apresentada

ao

Departamento de Direito da Pontifícia

Universidade Católica do Rio de

Janeiro (PUC-Rio) para a obtenção do

Título de Bacharel em Direito.

Orientador(a): Profa. Inês Alegria Rocumback 


\section{AGRADECIMENTOS}

Agradeço, primeiramente, aos meus pais Sílvia e Renato, pelo apoio, carinho e educação que me proporcionaram ao longo da vida. À minha mãe, especialmente, por ser minha melhor amiga e estar presente em todos os momentos, sejam bons ou ruins. E à meu pai, pelo incentivo na escolha do Direito como graduação e, principalmente, por toda a ajuda prestada.

Aos meus irmãos Luís Eduardo e Ana Carolina, pelo convívio diário e pelo companheirismo que nos vincula, sempre preenchendo a casa de alegrias, felicidades e muita união.

À outra pessoa que contempla meu cotidiano, meu namorado André, também de grande importância nesta jornada, sempre paciente, compreensivo e companheiro. Obrigada pelo apoio, cumplicidade e por dividir comigo o sonho de um futuro.

Agradeço também às amigas de infância que estiveram presentes nos principais momentos da minha vida, especialmente durante esta caminhada, sempre apoiando e incentivando.

Igualmente importante são os amigos da faculdade, não somente pelos cinco anos de convívio, mas agradeço também pela grande ajuda e amizade.

Agradeço ainda a Professora Inês Alegria Rocumback, primeiramente pela orientação deste trabalho, mas sobretudo pelo carinho, paciência e por ter ajudado a despertar em mim a paixão pelo Direito de Família.

Finalmente, os meus sinceros agradecimentos a todos os amigos e familiares que fizeram parte dessa caminhada e compreenderam minhas ausências e omissões. Muito obrigada. 


\section{RESUMO}

O presente estudo tem como objetivo principal analisar o cabimento de indenização por danos morais aos pais que abandonam afetivamente seus filhos, e para facilitar a pesquisa restringiu-se o tema apenas à hipótese de abandono paterno. Sendo assim, ponderamos as jurisprudências favoráveis e desfavoráveis à hipótese em Tribunais Brasileiros e analisamos a atual mudança de entendimento do Superior Tribunal de Justiça. Para tanto, o estudo foi elaborado percorrendo-se a evolução do conceito de família e de poder familiar ao longo dos anos, passando pelos direitos e deveres dos pais em relação aos filhos, até chegar nos princípios basilares do Direito de Família para a questão abordada. Tratou-se também da importância do cuidado e do afeto como valores jurídicos, observando que a criança e o adolescente devem ser tratados sempre em seu melhor interesse, como sujeitos de direito e na condição de ser humano em desenvolvimento. Ainda, o estudo abordou o tema da responsabilidade civil subjetiva, seus pressupostos e sua aplicação às hipóteses de abandono afetivo, passando pelas posições jurisprudenciais. Também foi ressaltada a importância do tema nos debates atuais demonstrando-se dois projetos de lei em tramitação sobre o assunto. E, ao final, concluiu-se pela possibilidade de compensação em danos morais por abandono afetivo paterno.

\section{PALAVRAS-CHAVE}

Paternidade. Abandono afetivo. Indenização. Danos morais. 


\section{SUMÁRIO}

INTRODUÇÃ

CAPÍTULO 1 - A FAMÍLIA...................................................................10

1.1 Evolução do conceito de família .....................................................10

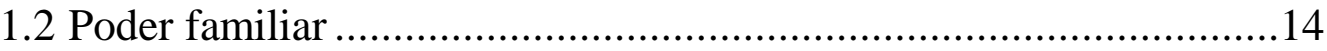

1.2.1 Do pátrio poder ao poder familiar .....................................14

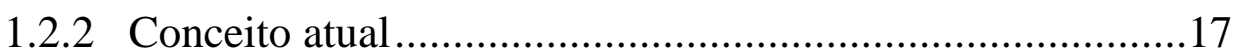

1.2.3 Direitos e deveres inerentes ao poder familiar ....................19

1.2.4 Suspensão, perda ou extinção do poder familiar..................21

CAPÍTULO 2 - PRINCÍPIOS DO DIREITO DE FAMÍLIA.............25

2.1 Princípio da dignidade da pessoa humana ..........................................26

2.2 Princípio da solidariedade familiar ................................................28

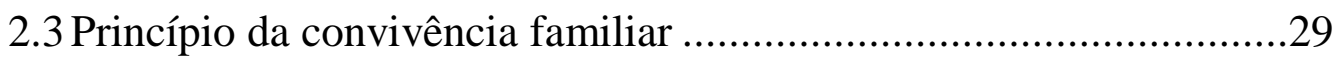

2.4 Princípios da prioridade absoluta, do melhor interesse da criança e da

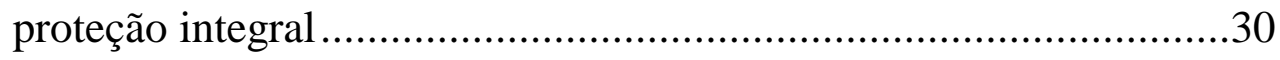

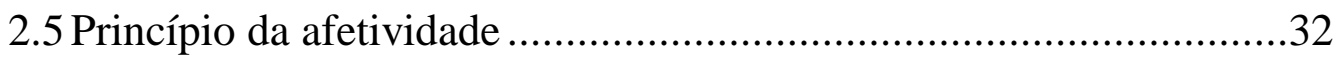

2.5.1 O afeto e o cuidado como valores jurídicos ..........................33

CAPÍTULO 3 - RESPONSABILIDADE CIVIL.................................37

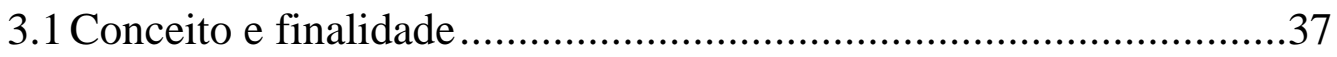

3.2 Pressupostos da responsabilidade civil subjetiva...............................38

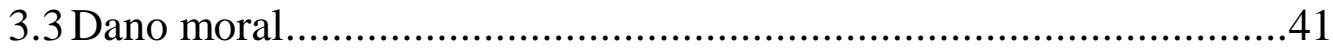

3.3.1 Quantificação do dano moral .............................................44

3.3.2 Dano moral nas relações familiares.....................................46

CAPÍTULO 4 - DANO MORAL POR ABANDONO AFETIVO ....49

4.1 $\mathrm{O}$ abandono afetivo e suas hipóteses................................................49 
4.2 Elementos da responsabilidade civil e sua aplicação ao abandono afetivo

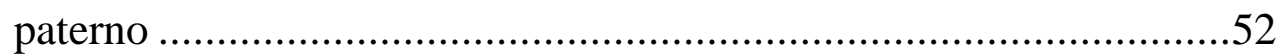

4.2.1 Conduta omissiva quanto aos deveres paternos ................52

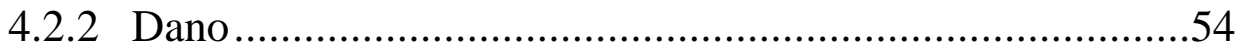

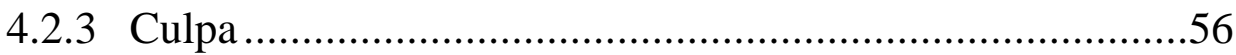

4.2.4 Nexo de causalidade .............................................57

4.3 Posições jurisprudenciais favoráveis à configuração do dano moral por

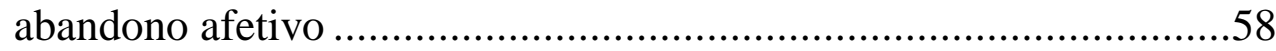

4.4 Posições jurisprudenciais desfavoráveis à configuração do dano moral por abandono afetivo 62

4.5 Posicionamento do Superior Tribunal de Justiça: mudança de entendimento 


\section{LISTA DE ABREVIAÇÕES}

CC - Código Civil

CF - Constituição Federal

ECA - Estatuto da criança e do adolescente

STJ - Superior Tribunal de Justiça 


\section{INTRODUÇÃO}

$\mathrm{O}$ presente trabalho tem como objeto central analisar o cabimento de uma indenização por danos morais nos casos de abandono afetivo paterno.

Como se irá demonstrar, o Direito de Família, passou por significativas transformações ao longo dos séculos, especialmente nas últimas décadas, deixando de ser um direito exclusivamente patrimonial, para se tornar um direito pessoal. Isto é, o patrimônio deixou de ser a base da relação familiar e o foco migrou para a pessoa humana e o seu pleno desenvolvimento.

Dessa forma, com a evolução da família e as transformações sofridas pelo ordenamento jurídico, o afeto, já consubstanciado no chamado princípio da afetividade, apesar de não estar positivado, ganhou elevado valor jurídico. E, sendo assim, já pode-se afirmar que, juntamente com o princípio da dignidade da pessoa humana, o princípio da afetividade tornouse importantíssimo para a definição atual de entidade familiar.

O primeiro capítulo pretende, então, explicitar a evolução que o conceito de família sofreu ao longo dos anos, passando de patriarcal, hierarquizada e biológica para uma família democrática, igualitária e socioafetiva.

Após a explanação das modificações que a ideia de família sofreu, ainda de grande importância para o presente estudo será demonstrar a evolução que o poder familiar percorreu ao longo desses anos. E, desta forma, o capítulo primeiro também vai expor o conceito de pátrio poder e sua mudança para o atual poder familiar, os direito e deveres a ele inerentes e as causas de sua extinção, perda ou suspensão.

Tamanha a importância dos princípios para o Direito de Família e, especialmente, para este estudo, restou adequado dispensar um capítulo inteiro ao seu aprofundamento. Desse modo, o segundo capítulo explicitará os princípios que foram considerados mais importantes para o desenrolar desta pesquisa, quais sejam, o princípio da dignidade da pessoa humana, da 
solidariedade familiar, da convivência familiar, da prioridade absoluta, do melhor interesse da criança, da proteção integral, e claro, o princípio da afetividade.

Quando da escolha do tema em estudo, uma das finalidades a se atingir era investigar como o assunto vem sendo tratado pelos Tribunais Brasileiros ao longo dos últimos anos e analisar a recente mudança de entendimento do Superior Tribunal de Justiça, estudando o precedente da Terceira Turma do STJ que condenou um pai a indenizar sua filha no valor de $\mathrm{R} \$ 200.000,00$ (duzentos mil reais) por tê-la abandonado afetivamente, negligenciando assim a prestação de assistência imaterial.

Por isso, mister se faz estudar como o afeto e o cuidado vêm sendo tratados, uma vez que a Relatora do caso paradigma, Ministra Nancy Andrighi, se utilizou amplamente da ideia de cuidado como dever legal dos pais na criação de seus filhos, baseando quase toda a explicação de seu voto nessa premissa. Assim, se dispensará tópico exclusivo à análise do cuidado e do afeto como valores jurídicos.

Ainda, para analisar o cabimento de danos morais nos casos de abandono afetivo, não se pode deixar de estudar o tema da responsabilidade civil, o que se faz no terceiro capítulo, o qual iniciará percorrendo seu conceito e finalidade.

O tema do presente trabalho envolve a chamada responsabilidade civil subjetiva, motivo pelo qual percorreremos seus pressupostos (conduta culposa, dano e nexo causal), explicando como a doutrina conceitua estes elementos. E depois, partindo então para o dano que mais importa neste estudo, isto é, o dano moral, apresentaremos, ainda no terceiro capítulo, seu conceito, como se dá sua quantificação, e por fim, seu cabimento nas relações familiares.

Ultrapassadas estas conceituações gerais, mas que se fazem necessárias, no quarto capítulo adentraremos a análise central do estudo, ou seja, o dano moral por abandono afetivo. Dessa forma, apresentaremos incialmente algumas hipóteses de abandono afetivo e faremos as ligações 
indispensáveis entre os elementos caracterizadores da responsabilidade civil e sua aplicação direta ao abandono afetivo.

No intuito de facilitar o desenvolvimento do trabalho, restringiremos a hipótese de abandono afetivo somente ao caso em que o pai abandona afetivamente seus filhos, ou seja, apesar de o abandono genericamente poder ser do pai ou da mãe em relação a sua prole, utilizaremos somente os casos de abandono paterno.

Em momento seguinte, pretendendo analisar as jurisprudências sobre o tema, passaremos a expor as posições favoráveis à configuração do dano moral por abandono afetivo, depois demonstraremos as posições desfavoráveis. E por fim e de suma importância, adentraremos a análise da mudança de entendimento do STJ, apontando a posição que vinha sendo adotada até os dias atuais e a criação do que pode vir a ser um novo paradigma jurisprudencial.

Considerando a enorme importância deste tema, e para exemplificar os grandes debates que ocorrem nos dias atuais, se faz relevante trazer, no quinto capítulo, a análise de dois projetos de lei que tramitam atualmente no Congresso Nacional. Um visando caracterizar o abandono moral como ilícito civil e penal, e outro com o fim de estabelecer a possibilidade de indenização por dano moral em razão do abandono afetivo.

E por fim, o estudo se encerrará com um tópico de conclusão, no qual serão apresentados os pontos conclusivos sobre a pesquisa desenvolvida em âmbito doutrinário, jurisprudencial e legislativo.

Portanto, claro está o objetivo central desta pesquisa, que pretende demonstrar que é possível o cabimento de indenização por danos morais aos pais que abandonam afetivamente seus filhos. 


\section{CAPÍTULO 1 - A FAMÍLIA}

\section{1 - Evolução do conceito de família}

Durante muitos séculos, a família, baseada na ideia do patriarcalismo, foi conceituada como um organismo extenso e hierarquizado ${ }^{1}$, isto é, a entidade familiar era organizada sob o princípio da autoridade e abarcava todos que a ela estavam submetidos ${ }^{2}$.

O pater, sempre representado pela figura paterna, era quem liderava toda a família, uma vez que se encontrava em uma posição hierárquica superior e detinha todos os poderes de administração e gestão da unidade familiar. Sendo assim, desde a época romana se percebe essa importância da figura masculina nas relações familiares, porque sendo considerado como chefe, o pater detinha o controle da família e também o chamado pátrio poder.

A figura do pater representava, em uma única pessoa, todos os prismas que a unidade familiar possuía, ou seja, o pai era considerado o líder politico, econômico, jurisdicional e religioso. Era ele quem detinha poder sobre a esposa, os filhos, os escravos e todo o patrimônio familiar.

Segundo Venosa:

Em Roma, o poder do pater exercido sobre a mulher, os filhos e os escravos é quase absoluto. A família como grupo é essencial para a perpetuação do culto familiar. No Direito romano, assim como no grego, o afeto natural, embora pudesse existir, não era o elo de ligação entre os membros da família. ${ }^{3}$

Essa herança romana teve grandes reflexos em toda a história do direito de família brasileiro. Até o século XX, especialmente até meados dos anos 60 quando surgiu o Estatuto da Mulher Casada (Lei 4.121/62), a mulher ainda era vista como inferior perante o marido, não possuindo

\footnotetext{
${ }^{1}$ PEREIRA, Caio Mário da Silva. Instituições de Direito Civil: Direito de Família. $18^{\text {a }}$ ed. Rio de Janeiro: Forense, 2010. p. 23.

${ }^{2}$ Ibid. p. 28.

${ }^{3}$ VENOSA, Sílvio de Salvo. Direito civil: Direito de família. $4^{\mathrm{a}}$ ed. São Paulo: Atlas, 2004. p. 18.
} 
qualquer autonomia ou independência. Tanto a esposa quanto os filhos viviam sob a subordinação e liderança do pai, que até então era visto como o chefe da família.

Ensina Maria Berenice Dias:

A família tinha uma formação extensiva, verdadeira comunidade rural, integrada por todos os parentes, formando unidade de produção, com amplo incentivo à procriação. Sendo entidade patrimonializada, seus membros eram força de trabalho. O crescimento da família ensejava melhores condições de sobrevivência a todos. O núcleo familiar dispunha de perfil hierarquizado e patriarcal. ${ }^{4}$

E no mesmo sentido, discorre Rolf Madaleno:

A família do passado não tinha preocupações com o afeto e a felicidade das pessoas que formavam seu principal núcleo, pois eram os interesses de ordem econômica que gravitavam em torno daquelas instâncias de famílias construídas com suporte na aquisição de patrimônio. ${ }^{5}$

Acontece que, com a ocorrência da Revolução Industrial e sua expansão através do século XIX, as famílias migraram do campo para os centros urbanos em busca de empregos nas novas indústrias. E a partir daí, a ideia de família ganhou uma nova aparência, com as mulheres trabalhando fora do lar, ganhando seu próprio salário e, assim, maior autonomia. Diferentemente do que se via, elas passam a ter papel de importância na família e no seu sustento.

Conforme prossegue Dias:

"Esse quadro não resistiu à revolução industrial, que fez aumentar a necessidade de mão de obra, principalmente para desempenhar atividades terciárias. Foi assim que a mulher ingressou no mercado de trabalho, deixando o homem de ser a única fonte de subsistência da família, que se tornou nuclear, restrita ao casal e sua prole. Acabou a prevalência do caráter produtivo e reprodutivo da família, que migrou para as cidades e passou a conviver em espaços menores. Isso levou à aproximação dos seus membros, sendo mais prestigiado o vínculo afetivo que envolve seus integrantes." 6

\footnotetext{
${ }^{4}$ DIAS, Maria Berenice. Manual de Direito das Famílias. $8^{\mathrm{a}}$ ed. São Paulo: Revista dos Tribunais, 2011. p. 28.

${ }^{5}$ MADALENO, Rolf. Curso de Direito de Família. $4^{\mathrm{a}}$ ed. Rio de Janeiro: Forense, 2011. p. 5.

${ }^{6}$ DIAS, Maria Berenice. Op. cit., p. 28.
} 
Pode-se notar então que aos poucos a família deixa de ser vista como uma unidade produtiva e sofre uma redução numérica bastante significativa, na qual passa-se a conviver em uma unidade habitacional menor somente os pais e seus descendentes. Surge a unidade familiar formada apenas por pais e filhos. Consequentemente, os laços afetivos entre os membros se aproximam, fazendo com que a proteção e o afeto nasçam no seio familiar com maior intensidade e valor.

Todavia, por mais que a família estivesse mudando de "aparência", no Brasil, até a promulgação da Constituição Federal de 1988, ela só possuiria existência legal e social se surgisse de um casamento válido e eficaz. Ou seja, a família brasileira era eminentemente matrimonializada e o ordenamento jurídico só reconhecia a sua legitimidade pela união através do casamento e também só reconhecia como legítimos os filhos originados dessa união. ${ }^{7}$

Durante muitos anos os filhos concebidos fora do casamento foram considerados ilegítimos, não possuindo qualquer proteção do sistema jurídico brasileiro, e as relações que hoje chamamos de união estável eram totalmente discriminados pela sociedade, também não possuindo qualquer tutela do ordenamento.

O Código Civil de 1916 apresentava claramente esta visão discriminatória do ente familiar, já que o limitava somente ao grupo originário do casamento, impedindo sua dissolução, distinguia seus membros e aplicava qualificações discriminatórias às pessoas unidas sem casamento e aos filhos havidos dessa relação. ${ }^{8}$

Contudo, com o advento da Carta Maior em 1988 e a positivação do princípio da dignidade da pessoa humana, o ser humano passou a ganhar maior importância. O Estado assumiu importante papel na proteção da entidade familiar como um todo, que desde então pode ser constituída de

\footnotetext{
${ }^{7}$ MADALENO, Rolf. Curso de Direito de Família. $4^{\mathrm{a}}$ ed. Rio de Janeiro: Forense, 2011. p. 27-28.

${ }^{8}$ HIRONAKA, Giselda Maria Fernandes Novaes; OLIVEIRA, Euclides de. Do Direito de Família. In: DIAS, Maria Berenice; PEREIRA, Rodrigo da Cunha (Coords.). Direito de Família e o Novo Código Civil. $4^{\mathrm{a}}$ ed. rev. e atual. Belo Horizonte: Del Rey, 2005. p. 3.
} 
diferentes maneiras, podendo se originar do casamento civil, da união estável ou até da monoparentalidade. ${ }^{9}$

Indo além, nos dias atuais e com a evolução do chamado princípio da afetividade, a família não está presa somente a esses três prismas trazidos pela CF de 1988, mas sim encontra no afeto e no amor seu ponto principal. Seja na paternidade socioafetiva, nas famílias reconstituídas ou famílias plurais, seja nas uniões homoafetivas ou nas adoções, nota-se que os princípios da afetividade e da dignidade da pessoa humana se tornaram os princípios basilares na constituição do conceito de família.

Ensina Rolf Madaleno:

A família contemporânea encontra sua realização no seu grupo e, dentro deste grupo familiar, cada um de seus integrantes encontra na convivência solidária e no afeto o valor social e jurídico que a família exerce no desenvolvimento da sociedade e do Estado. ${ }^{10}$

Vale frisar que, deixando de lado o patriarcalismo, não somente no afeto e no amor se baseia o surgimento das novas famílias, mas também na solidariedade, reciprocidade, assistência mútua, liberalidade, respeito mútuo e, principalmente, no enfoque que passa a ser dado à pessoa humana e ao seu pleno desenvolvimento. Sendo assim, os novos agrupamentos familiares se formam com especial atenção voltada ao crescimento e realização individual de cada um de seus membros.

Dessa maneira, a família matrimonializada, hierarquizada, patriarcal, heteroparental, biológica e institucional, que era vista como unidade de produção e de reprodução cedeu lugar para uma família pluralizada, hetero ou homoparental, biológica ou socioafetiva, democrática e igualitária, construída sempre com base na afetividade e de caráter instrumental. ${ }^{11}$

Não se está pretendendo dizer que o conceito atual de família está em decadência. Pelo contrário, ela é o resultado das transformações sociais. Houve uma repersonalização das relações familiares na busca do

\footnotetext{
${ }^{9}$ MADALENO, Rolf. Curso de Direito de Família. $4^{\mathrm{a}}$ ed. Rio de Janeiro: Forense, 2011. p. 28.

${ }^{10}$ Ibid. p. 5 .

${ }^{11}$ Ibid. p. 28.
} 
atendimento aos interesses mais valiosos das pessoas humanas: afeto, lealdade, solidariedade, confiança, respeito e amor. ${ }^{12}$

Na moderna ideia de família, o mais importante para cada um de seus membros é pertencer ao seu âmago, é estar naquele idealizado lugar onde é possível integrar valores, sentimentos e esperanças, permitindo, a cada um, se sentir a caminho da realização de seu projeto pessoal de felicidade. $^{13}$

\section{2 - Poder familiar}

\subsection{1 - Do pátrio poder ao poder familiar}

A estrutura autocrática da família no direito antigo, baseada no princípio da autoridade, formou a noção de pátrio poder em termos severos e rígidos, não lhe faltando a influência religiosa, já que o chefe da família pater - era, também o sacerdote do culto doméstico. ${ }^{14}$ Dessa forma, o pátrio poder tem alicerce religioso e politico, já que o pater era visto como o sacerdote do culto e como o chefe da família.

Como já dito, no modelo romano de família também predominava o princípio da autoridade do pater famílias, que exercia uma incontestável chefia sobre as pessoas a ele subordinadas, que lhe deviam total obediência, fosse a esposa, os filhos, irmãos, netos, escravos ou quem se assemelhasse. $^{15}$

Em Roma, o pater possuía, inclusive, o direito de matar, vender ou abandonar o filho, estendendo-se esse direito até o período da República,

\footnotetext{
${ }^{12}$ DIAS, Maria Berenice. Manual de Direito das Famílias. $8^{\text {a }}$ ed. São Paulo: Revista dos Tribunais, 2011. p. 34.

${ }^{13}$ HIRONAKA, Giselda Maria Fernandes Novaes; OLIVEIRA, Euclides de. Do Direito de Família. In: DIAS, Maria Berenice; PEREIRA, Rodrigo da Cunha (Coords.). Direito de Família e o Novo Código Civil. $4^{\mathrm{a}}$ ed. rev. e atual. Belo Horizonte: Del Rey, 2005. p. 3.

${ }^{14}$ PEREIRA, Caio Mário da Silva. Instituições de Direito Civil: Direito de Família. $18^{\mathrm{a}}$ ed. Rio de Janeiro: Forense, 2010. p. 445.

${ }^{15}$ MADALENO, Rolf. Curso de Direito de Família. $4^{\mathrm{a}}$ ed. Rio de Janeiro: Forense, 2011. p. 653.
} 
embora já com alguma moderação. Contudo, apenas no século II e com influências de Justiniano, o chefe de família teve seus poderes limitados apenas ao direito de correção dos atos dos filhos. ${ }^{16}$

Em âmbito nacional, no Brasil colonial, sob as Ordenações e Leis do Reino de Portugal, o pai possuía um domínio praticamente absoluto sobre os filhos, sua mulher e seus escravos, os quais deveriam sempre cumprir sua autoridade. Inclusive, o poder paterno autorizava o pai a corrigir e castigar, de forma moderada, seus filhos. ${ }^{17}$

Ocorre que, com a influência do cristianismo, o pátrio poder assumiu características de direito protetivo, no qual os pais não mais exercem um poder absoluto sobre seus filhos, mas sim assumem um dever natural e legal de proteção de seus descendentes, acompanhando sua prole durante todo o processo de amadurecimento e formação de sua personalidade. ${ }^{18}$

Segundo Orlando Gomes, o instituto do pátrio poder perdeu sua organização despótica inspirada no direito romano, deixando de ser um conjunto de direitos, amplo e ilimitados, do pai sobre os filhos, para se tornar um complexo de deveres ${ }^{19}$, que deve ser exercido por ambos os pais, como se demonstrará mais adiante.

Desse modo, o pátrio poder passou a não mais se caracterizar apenas na figura do pater, mas sim na figura de ambos os pais, que possuem juntamente diversos deveres e direitos para proteção e cuidado de sua prole.

Essa mudança é claramente constatada com a alteração que o texto original da Lei 3.071/16 (Código Civil de 1916) sofreu com o advento da Lei 4.121/62 (Estatuto da Mulher Casada), já que no texto original o pátrio poder era concedido exclusivamente ao marido, e na sua falta à mulher, e posteriormente, o pátrio poder, apesar de ainda ser concedido ao pai, passou a ser exercido pelo marido com a colaboração da mãe, sua mulher.

Como pode-se notar no texto original da Lei 3.071/16:

\footnotetext{
${ }^{16}$ MADALENO, Rolf. Curso de Direito de Família. $4^{\mathrm{a}}$ ed. Rio de Janeiro: Forense, 2011. p. 653.

${ }^{17}$ Ibid. p. 654.

${ }^{18}$ Ibid. p. 654.

${ }^{19}$ GOMES, Orlando. Direito de família. $11^{\text {a }}$ ed. Rio de Janeiro: Forense, 1999. p. 389.
} 
Art. 380. Durante o casamento, exerce o pátrio poder o marido, como chefe da família (art. 233), e, na falta ou impedimento seu, a mulher.

E após a Lei 4.121/62, a redação passaria a ser a seguinte:

Art. 380. Durante o casamento compete o pátrio poder aos pais, exercendo-o o marido com a colaboração da mulher. Na falta ou impedimento de um dos progenitores, passará o outro a exercê-lo com exclusividade. (Redação dada pela Lei ${ }^{\circ}$ 4.121, de 27.8.1962)

Parágrafo único. Divergindo os progenitores quanto ao exercício do pátrio poder, prevalecerá a decisão do pai, ressalvado à mãe o direito de recorrer ao juiz para solução da divergência. (Incluído pela Lei no 4.121 , de 27.8.1962)

Contudo, tal mudança se torna ainda mais clara com o advento da CF de 1988 e o Estatuto da Criança e do Adolescente (Lei 8.069/90). Põese fim à qualquer distinção entre marido e mulher, trazendo a igualdade jurídica entre os cônjuges, e ainda, retira-se a prevalência da decisão paterna em caso de divergência, devendo os pais recorrerem ao juiz em caso de discórdia, já que não mais existe a ideia de colaboração, mas sim agora há um dever de ambos os pais exercerem juntamente, em igualdade de condições, o pátrio poder, não podendo prevalecer um sobre o outro.

Assim prevê o artigo $226, \S 5^{\circ}$ da CF de 1988:

Art. 226. A família, base da sociedade, tem especial proteção do Estado.

[...]

$\S 5^{\circ}$. Os direitos e deveres referentes à sociedade conjugal são exercidos igualmente pelo homem e pela mulher.

Já a Lei 8.069/90 (ECA), assim dispõe em seu artigo 21:

Art. 21. O Pátrio poder será exercido, em igualdade de condições, pelo pai e pela mãe, na forma do que dispuser a Legislação Civil, assegurado a qualquer deles o direito de, em caso de discordância, recorrer à autoridade judiciária competente para a solução de divergência.

Sendo assim, abandonou-se de vez a atribuição do pátrio poder apenas ao pai, extinguindo-se a submissão da mulher ao marido. Por outro lado, esse passou a ser confiado aos pais, como expressão da igualdade jurídica dos cônjuges. Por conta disso, diversos autores propuseram a 
substituição da velha nomenclatura por novas, como: "poder parental”, “autoridade parental" ou até "poder-dever". ${ }^{20}$

Por fim, com todas essas transformações, o Código Civil de 2002 (Lei 10.406/02) inovou quanto a nomenclatura do referido instituto, e o antigo pátrio poder passou a ser chamado de poder familiar, como pode-se notar no artigo 1.631 do $\mathrm{CC}$ atual:

Art. 1.631. Durante o casamento e a união estável, compete o poder familiar aos pais; na falta ou impedimento de um deles, o outro o exercerá com exclusividade. Parágrafo único. Divergindo os pais quanto ao exercício do poder familiar, é assegurado a qualquer deles recorrer ao juiz para solução do desacordo.

Valendo frisar, somente a título de curiosidade, que a atual nomenclatura também continuou sofrendo críticas de alguns doutrinadores, no sentido de que as palavras "poder" e "familiar" não seriam as mais apropriadas, contudo, apesar dos julgamentos doutrinários, o instituto ainda é atualmente denominado de "poder familiar".

\subsection{2 - Conceito atual}

Após a Constituição de 1988, Caio Mário conceituou o instituto do poder familiar como o "complexo de direitos e deveres quanto à pessoa e bens do filho, exercidos pelos pais na mais estreita colaboração, e em igualdade de condições". 21

No mesmo sentido, Guilherme Couto de Castro definiu o poder familiar como sendo "o conjunto de direitos e obrigações, quanto à pessoa e bens do filho menor, exercido pelos pais em proveito do infante ou adolescente." 22

\footnotetext{
${ }^{20}$ PEREIRA, Caio Mário da Silva. Instituições de Direito Civil: Direito de Família. $18^{a}$ ed. Rio de Janeiro: Forense, 2010. p. 447.

${ }^{21}$ Ibid. p. 448.

${ }^{22}$ CASTRO, Guilherme Couto de. Direto Civil: lições: parte geral, obrigações, responsabilidade civil, reais, família e sucessões. $4^{a}$ ed. Rio de Janeiro: Impetus, 2011. p. 365.
} 
Vale frisar que este poder somente é exercido pelos pais, sejam biológicos ou adotivos. Em caso de falta destes, as atribuições inerentes a criação e educação da criança são confinadas a terceiros, mas que não exercem o poder familiar, e sim a tutela do menor. ${ }^{23}$

O poder familiar passa a ter como foco constitucional principal o melhor interesse da criança e do adolescente, e não mais a prevalência da vontade paterna como chefe da sociedade familiar. E assim caminhou toda a legislação infraconstitucional, ao atribuir aos pais, com absoluta igualdade de prerrogativas e deveres, as tarefas de criar, educar e zelar pelos aspectos materiais e morais de toda a sua prole. ${ }^{24}$

Logo, é ao mesmo tempo dever e interesse natural dos pais propiciarem as melhores condições para os seus filhos, tanto no que diz respeito à educação e formação como quanto aos interesses físicos, sociais, intelectuais, morais e afetivos, já que todos esses elementos contribuem na boa estruturação intelectual e psíquica do menor. ${ }^{25}$

Frisa-se, evidentemente, que estão submetidos ao poder familiar tanto os filhos naturais, oriundos ou não do casamento, como os socioafetivos e os adotivos, todos enquanto menores de dezoito anos, figurando neste contexto um conjunto de direitos e deveres recíprocos. ${ }^{26}$

Assim trata o artigo 20 do ECA:

“Art. 20. Os filhos, havidos ou não da relação do casamento, ou por adoção, terão os mesmos direitos e qualificações, proibidas quaisquer designações discriminatórias relativas à filiação."

O poder familiar é imprescritível, irrenunciável, inalienável e indelegável. ${ }^{27} \mathrm{O}$ que significa que os pais não podem delegá-lo a terceiros como mera transferência ou transação, também não decaem de seu direito

\footnotetext{
${ }^{23}$ NADER, Paulo. Curso de direito civil: Direito de família. Volume 5. $2^{\mathrm{a}}$ ed. Rio de Janeiro: Forense, 2008. p. 331.

${ }^{24}$ MADALENO, Rolf. Curso de Direito de Família. 4 ed. Rio de Janeiro: Forense, 2011. p. 654.

${ }^{25}$ Ibid. p. 656.

${ }^{26}$ Ibid. p. 656.

${ }^{27}$ CASTRO, Guilherme Couto de. Direto Civil: lições: parte geral, obrigações, responsabilidade civil, reais, família e sucessões. $4^{\mathrm{a}}$ ed. Rio de Janeiro: Impetus, 2011. p. 366.
} 
ao deixar de exercê-lo, e muito menos podem abdicar de seus direitos e deveres como pais.

Assim, conforme ensina Paulo Lôbo, o poder familiar, sendo menos poder e mais dever, converteu-se em múnus, concebido como encargo legalmente atribuído a alguém, em virtude de certas circunstâncias, a que se não pode fugir." 28

\subsection{3 - Direitos e deveres inerentes ao poder familiar}

Os poderes e deveres próprios do exercício do poder familiar dizem respeito à pessoa e aos bens dos filhos menores. Na ordem pessoal, estes atributos se manifestam sob três aspectos fundamentais: guarda, correição e educação, e todos eles sendo, ao mesmo tempo, um direito e um dever. ${ }^{29}$

Assim dispõe o artigo 229 da CF de 1988:

Art. 229. Os pais têm o dever de assistir, criar e educar os filhos menores, e os filhos maiores têm o dever de ajudar e amparar os pais na velhice, carência ou enfermidade.

Nesse mesmo sentido vêm os artigos 22 do ECA e 1.634 do CC de 2002:

Art. 22. Aos pais incumbe o dever de sustento, guarda e educação dos filhos menores, cabendo-lhes ainda, no interesse destes, a obrigação de cumprir e fazer cumprir as determinações judiciais.

Art. 1.634. Compete aos pais, quanto à pessoa dos filhos menores:

I - dirigir-lhes a criação e educação;

II - tê-los em sua companhia e guarda;

III - conceder-lhes ou negar-lhes consentimento para casarem;

IV - nomear-lhes tutor por testamento ou documento autêntico, se o outro dos pais não lhe sobreviver, ou o sobrevivo não puder exercer o poder familiar;

$\mathrm{V}$ - representá-los, até aos dezesseis anos, nos atos da vida civil, e assisti-los, após essa idade, nos atos em que forem partes, suprindo-lhes o consentimento; VI - reclamá-los de quem ilegalmente os detenha;

\footnotetext{
${ }^{28}$ LÔBO, Paulo Luiz Netto. Direito Civil: famílias. $4^{\text {a }}$ ed. São Paulo: Saraiva, 2011. p. 297.

${ }^{29}$ GOMES, Orlando. Direito de família. $11^{\mathrm{a}}$ ed. Rio de Janeiro: Forense, 1999. p. 389.
} 
VII - exigir que lhes prestem obediência, respeito e os serviços próprios de sua idade e condição.

Conforme ensina Madaleno, em primeiro lugar, como dever principal e prioritário, devem os pais assistir seus filhos, na mais ampla e total proteção, tanto na função alimentar quanto na função de guarda, segurança e companhia, zelando pela integridade moral e psíquica de sua prole e oferecendo sempre o suporte necessário para conduzi-los ao completo desenvolvimento e independência. ${ }^{30}$

Prossegue o autor:

sob o prisma do artigo 1.634 do Código Civil, o dever dos pais de criarem os filhos menores deve ser compreendido como o ato de promover o seu sadio crescimento, e assegurar à prole, com absoluta prioridade, a efetivação dos direitos inerentes à vida, à saúde, à alimentação, à educação, ao esporte, ao lazer, a profissionalização, à cultura, à dignidade, ao respeito, à liberdade e à convivência familiar e comunitária $\left(\mathrm{CF}\right.$, art. 227 ; ECA, art. $\left.4^{\circ}\right) .{ }^{31}$

O dever de educar que os pais possuem, além de englobar o aprendizado formal, compreendido pelo desenvolvimento intelectual, pessoal e o ensino escolar, abrange também o dever de passarem para os filhos seus conhecimentos "informais", que se traduziria na ideia de educar os filhos para o enfrentamento da vida, repassando seus ideários de vida, valores morais e éticos, sociais e afetivos. ${ }^{32}$

Com vistas a essa melhor formação da criança e do adolescente, o dever dos pais de guarda e companhia também é de suma importância, pois os filhos dependem da presença, proteção, cuidado e continua orientação de seus genitores, e é dessa convivência que nasce a natural troca de sentimentos, informações, experiências e, sobretudo, a troca de afeto entre pais e filhos. ${ }^{33}$

Ainda aos filhos cabe o dever de obediência e respeito aos pais, incluindo o cumprimento de tarefas compatíveis com a sua idade e

\footnotetext{
${ }^{30}$ MADALENO, Rolf. Curso de Direito de Família. $4^{\mathrm{a}}$ ed. Rio de Janeiro: Forense, 2011. p. 658.

${ }^{31}$ Ibid. p. 658.

${ }^{32}$ Ibid. p. 659 .

${ }^{33}$ Ibid. p. 654.
} 
condições. E, em contrapartida, aos pais, detentores do poder familiar, caberá o dever de cobrar tais condutas dos filhos menores. ${ }^{34}$

Vale destacar, dentre seus diversos direitos e deveres, que aos pais também compete o usufruto e a administração do patrimônio dos filhos menores, que deve ser praticado sempre com zelo e eficiência. ${ }^{35}$

Contudo, apesar de todos esses deveres citados, ensina Dias:

Nesse extenso rol não consta o que talvez seja o mais importante dever dos pais com relação aos filhos: o dever de lhes dar amor, afeto e carinho. A missão constitucional dos pais, pautada nos deveres de assistir, criar e educar os filhos menores, não se limita a vertentes patrimoniais. A essência existencial do poder familiar é a mais importante, que coloca em relevo a afetividade responsável que liga pais e filhos, propiciada pelo encontro, pelo desvelo, enfim, pela convivência familiar. $^{36}$

\subsection{4 - Suspensão, perda ou extinção do poder familiar}

A separação judicial, o divórcio e a dissolução da união estável não alteram o exercício do poder familiar, salvo quanto ao direito de ter a guarda dos filhos. Ou seja, a falta de convivência sob o mesmo teto não limita nem exclui o poder-dever dos pais, que permanece inalterado, exceto no que tange ao direito de terem os filhos em sua companhia. Sendo assim, a convivência dos pais não é requisito para a titularidade do poder familiar. $^{37}$

Conforme preceitua o artigo 1.632 do Código Civil atual:

Art. 1632. A separação judicial, o divórcio e a dissolução da união estável não alteram as relações entre pais e filhos senão quanto ao direito, que aos primeiros cabe, de terem em sua companhia os segundos.

\footnotetext{
${ }^{34}$ NADER, Paulo. Curso de direito civil: Direito de família. Volume 5. $2^{\mathrm{a}}$ ed. Rio de Janeiro: Forense, 2008. p. 339.

${ }^{35}$ Ibid. p. 339.

${ }^{36}$ DIAS, Maria Berenice. Manual de Direito das Famílias. $8^{\mathrm{a}}$ ed. São Paulo: Revista dos Tribunais, 2011. p. 429.

${ }^{37}$ Ibid. p. 428.
} 
Contudo, como o poder familiar é um dever a ser exercido fundamentalmente no interesse do filho menor, o Estado pode interferir nessa relação, e a lei vem disciplinar os casos em que o titular pode ser privado de seu exercício, temporária ou definitivamente. ${ }^{38}$

Assim dispõe o artigo 1.635 do CC sobre a extinção do poder familiar:

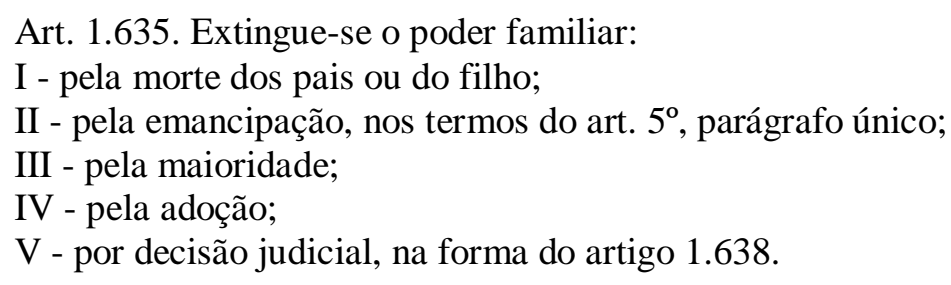

Quanto ao inciso I, é sabido que a morte de um dos pais não extingue o poder familiar, que permanece com o genitor sobrevivente. Conforme Lôbo, a morte apenas extingue o poder familiar se for de ambos os pais, já que o pai ou a mãe sobrevivente terão o poder familiar de forma exclusiva, enquanto viver e o filho não atingir a maioridade. ${ }^{39}$

Já quanto aos incisos II, III e IV, Venosa explica que a emancipação do filho importa atribuir-lhe completa capacidade de direito. A maioridade é a forma normal de extinção do poder familiar. E por último, a adoção, qualquer que seja sua modalidade, extingue o poder familiar da família original, que passa a ser exercido pela família adotante. Então, na verdade, a adoção não extingue o poder familiar, mas sim o transfere. ${ }^{40}$

Por último, quanto ao inciso $\mathrm{V}$, a decisão judicial na forma do artigo 1.638 é aquela que conclui por um dos fatos graves ali descritos, que se mostram incompatíveis com o poder familiar. A perda deste poder por ato judicial é a mais grave sanção imposta aos pais que faltam com seus deveres em relação aos filhos. ${ }^{41}$

Dispõe o artigo 1.638 do CC:

\footnotetext{
${ }^{38}$ VENOSA, Sílvio de Salvo. Direito civil: Direito de família. $4^{\text {a }}$ ed. São Paulo: Atlas, 2004. p. 379.

${ }^{39}$ LÔBO, Paulo Luiz Netto. Direito Civil: famílias. $4^{\text {a }}$ ed. São Paulo: Saraiva, 2011. p. 306.

${ }^{40}$ VENOSA, Sílvio de Salvo. Op. Cit., p. 380.

${ }^{41}$ Ibid. p. 380-382.
} 
Art. 1.638. Perderá por ato judicial o poder familiar o pai ou a mãe que:

I - castigar imoderadamente o filho;

II - deixar o filho em abandono;

III - praticar atos contrários à moral e aos bons costumes;

IV - incidir, reiteradamente, nas faltas previstas no artigo antecedente.

Como dito, a perda do poder familiar é sanção de grande alcance e corresponde à infringência de um desses deveres que são de extrema relevância. Entende-se que a perda da autoridade parental por ato judicial (artigo 1.638, CC) leva à sua extinção (artigo 1.635, V, CC), que seria o fim definitivo do poder familiar. Contudo, há de se admitir a possibilidade de revogação da medida, e com isso, utilizando como norte o principio da proteção integral dos interesses da criança, a perda do poder familiar não deve gerar sua extinção em toda e qualquer hipótese. ${ }^{42}$

Dessa forma, a extinção é hipótese de interrupção definitiva do poder familiar, e não se confunde com a perda ou com a suspensão, esta última que, decretada por autoridade judiciaria mediante apuração de conduta grave, impede o exercício do poder familiar durante certo tempo. ${ }^{43}$

Assim disciplina o artigo 1.637 do Código Civil:

Art. 1.637. Se o pai, ou a mãe, abusar de sua autoridade, faltando aos deveres a eles inerentes ou arruinando os bens dos filhos, cabe ao juiz, requerendo algum parente, ou o Ministério Público, adotar a medida que lhe pareça reclamada pela segurança do menor e seus haveres, até suspendendo o poder familiar, quando convenha.

Parágrafo único. Suspende-se igualmente o exercício do poder familiar ao pai ou à mãe condenados por sentença irrecorrível, em virtude de crime cuja pena exceda a dois anos de prisão.

A suspensão é medida muito menos gravosa, e está sujeita a revisão ou cancelamento, quando superadas as causas que a geraram. Também é facultativa, podendo o juiz deixar de exercê-la, já que as causas apresentadas no Código são genéricas, dando ampla margem a decisão do juiz. Pode ainda ser decretada com referência apenas a um filho e não

\footnotetext{
${ }^{42}$ DIAS, Maria Berenice. Manual de Direito das Famílias. $8^{\mathrm{a}}$ ed. São Paulo: Revista dos Tribunais, 2011. p. 436-437.

${ }^{43}$ LÔBO, Paulo Luiz Netto. Direito Civil: famílias. $4^{\text {a }}$ ed. São Paulo: Saraiva, 2011. p. 305-306.
} 
necessariamente a toda prole, como pode abranger apenas algumas prerrogativas do poder familiar. Por fim, em casos de má administração dos bens do menor, é possível o afastamento do genitor apenas da gestão dos bens, permanecendo ele com os demais encargos. ${ }^{44}$

Por fim, conclui-se que, por mais que a lei decline causas de suspensão e de extinção do poder familiar, estas são apresentadas de forma genérica, tendo o juiz ampla liberdade na identificação dos fatos que possam levar ao afastamento temporário ou definitivo das funções parentais. $^{45}$

${ }^{44}$ DIAS, Maria Berenice. Manual de Direito das Famílias. $8^{\text {a }}$ ed. São Paulo: Revista dos Tribunais, 2011. p. 435.

${ }^{45}$ Ibid. p. 434. 


\title{
CAPÍTULO 2 - PRINCÍPIOS DO DIREITO DE FAMÍLIA
}

\begin{abstract}
Segundo Dias:
É no direito das famílias onde mais se sente o reflexo dos princípios eleitos pela Constituição Federal, que consagrou como fundamentais valores sociais dominantes. Os princípios que regem o direito das famílias não podem distanciarse da atual concepção da família, dentro de sua feição desdobrada em múltiplas facetas. $^{46}$
\end{abstract}

Encontramos na Constituição Federal os mais variados princípios para o direito de família. Como ensina Madaleno, a Carta Magna colaciona diversos princípios, muito deles expressos, outros implícitos no espírito da Constituição, e dentre eles, vários endereçados ao direito de família. ${ }^{47}$

Dessa forma, José Sebastião de Oliveira, citado por Venosa, elenca um rol de princípios do direito de família que estão presentes na Constituição Federal, mas lembra que este rol não é exaustivo, dentre eles:

\begin{abstract}
Proteção de todas as espécies de famílias (art. 226, caput); reconhecimento expresso de outras formas de constituição familiar ao lado do casamento, como as uniões estáveis e as famílias monoparentais (art. $226, \S \S 3^{\circ}$ e $4^{\circ}$ ); igualdade entre os cônjuges (art. $5^{\circ}$, caput, I, e art. $226, \S 5^{\circ}$ ); dissolubilidade do vínculo conjugal e do matrimônio (art. 226, $\S 6^{\circ}$ ); dignidade da pessoa humana e paternidade responsável (art. 226, $\S 5^{\circ}$ ); assistência do estado a todas as espécies de família (art. 226, $\S 8^{\circ}$ ); dever de a família, a sociedade e o Estado garantirem à criança e ao adolescente direitos inerentes à sua personalidade (art. $227, \S \S 1^{\circ}, 2^{\circ}, 3^{\circ}, 4^{\circ}, 5^{\circ}$, $7^{\circ}$ ); igualdade entre os filhos havidos ou não do casamento, ou por adoção (art. $\left.227, \S 6^{\circ}\right)$; respeito recíproco entre pais e filhos; enquanto menores é dever daqueles assisti-los, criá-los e educá-los, e destes o de ampararem os pais na velhice, carência ou enfermidade (art. 229); dever da família, sociedade e Estado, em conjunto, ampararem as pessoas idosas, velando para que tenham uma velhice digna e integrada à comunidade (art. 230, CF) ${ }^{48}$
\end{abstract}

Mesmo com este vasto rol, percebe-se que é quase impossível elencar todos os princípios existentes. Sendo assim, alguns princípios merecem agora maior destaque em virtude de sua enorme importância para o desenrolar do presente trabalho.

\footnotetext{
${ }^{46}$ DIAS, Maria Berenice. Manual de Direito das Famílias. $8^{a}$ ed. São Paulo: Revista dos Tribunais, 2011. p. 61.

${ }^{47}$ MADALENO, Rolf. Curso de Direito de Família. $4^{\mathrm{a}}$ ed. Rio de Janeiro: Forense, 2011. p. 41.

${ }^{48}$ OLIVEIRA, José Sebastião de. apud VENOSA, Sílvio de Salvo. Direito civil: Direito de família. $4^{a}$ ed. São Paulo: Atlas, 2004. p. 30-31.
} 


\section{1 - Princípio da dignidade da pessoa humana}

Por trazer um conteúdo bastante subjetivo, o princípio da dignidade da pessoa humana encontra algumas dificuldades em sua conceituação.

Na lição de Ingo Wolfgang Sarlet, a dignidade da pessoa humana é:

a qualidade intrínseca e distintiva reconhecida em cada ser humano que o faz merecedor do mesmo respeito e consideração por parte do Estado e da comunidade, implicando, neste sentido, um complexo de direitos e deveres fundamentais que assegurem a pessoa tanto contra todo e qualquer ato de cunho degradante e desumano, como venham a lhe garantir as condições existenciais mínimas para uma vida saudável, além de propiciar e promover sua participação ativa e co-responsável nos destinos da própria existência e da vida em comunhão com os demais seres humanos. ${ }^{49}$

A Constituição democrática de 1988 explicitou, em seu artigo $1^{\circ}$, inciso III, a dignidade da pessoa humana como um dos fundamentos da República. ${ }^{50}$

Nessa linha, Farias e Rosenvald ensinam que a dignidade humana é o mais precioso valor da ordem jurídica brasileira, sendo erigido, pela Constituição Federal, como postulado fundamental. Assim, eleva o ser humano ao centro de todo sistema jurídico, englobando todos os valores e direitos que podem ser reconhecidos à pessoa humana, desde a afirmação de sua integridade física, psíquica e intelectual, até a garantia de sua autonomia e livre desenvolvimento da personalidade. ${ }^{51}$

Desse modo, na medida em que a Constituição Federal elevou a dignidade da pessoa humana a fundamento da ordem jurídica, houve uma opção expressa pela pessoa, ou seja, provocou-se uma despatrimonialização

\footnotetext{
${ }^{49}$ SARLET, Ingo Wolfgang. Dignidade da Pessoa Humana e Direitos Fundamentais na Constituição Federal de 1988. $4^{\mathrm{a}}$ ed. Porto Alegre: Livraria do Advogado, 2006. p 60.

${ }^{50}$ MORAES, Maria Celina Bodin. Danos morais e relações de família. In: PEREIRA, Rodrigo da Cunha (Coord.). Afeto, ética, família e o novo Código Civil brasileiro: anais do IV Congresso Brasileiro de Direito de Família. Belo Horizonte: IBDFAM, Ordem dos Advogados do Brasil, Del Rey, 2004. p. 407.

${ }^{51}$ FARIAS, Cristiano Chaves de; ROSENVALD, Nelson. Direito Civil: Teoria Geral. $8^{\mathrm{a}}$ ed. Rio de Janeiro: Lumen Juris, 2009. p. 124.
} 
e a personalização dos institutos jurídicos, de modo a colocar a pessoa humana no centro de proteção do direito. ${ }^{52}$

Vale ressaltar que a dignidade da pessoa humana, como um princípio que consagra os mais importantes valores do ordenamento jurídico, não está presente somente no artigo $1^{\circ}$ da $\mathrm{CF}$, mas também encontra respaldo no artigo $226, \S 7^{\circ}$, ao tratar do planejamento familiar, e no artigo 227 , que traz como dever da família, do Estado e da sociedade assegurar à criança e ao adolescente o direito à dignidade.

Tal princípio também integra, além do texto constitucional, o ECA, em seus artigos 15 e 18, os quais asseguram às crianças e aos adolescentes o direito à dignidade como pessoas humanas em processo de desenvolvimento e como sujeitos de direitos, e ainda, estabelecem como dever de todos velar pela dignidade dos mesmos, colocando-os a salvo de qualquer tratamento desumano, vexatório, violento, aterrorizante ou constrangedor.

Sendo assim, estas disposições legais trazem deveres destinados a todos os cidadãos, para que protejam os menores de qualquer maldade ou constrangimento a que estão sujeitos, em prol de obterem um desenvolvimento sem qualquer tipo de trauma.

Ainda, além da abster-se de praticar atos atentatórios à dignidade humana, importante frisar que todos devem assegurar às crianças e aos adolescentes uma vida digna, respeitando seus direitos e garantindo um mínimo existencial, para assim formar adultos completos e com plena realização de sua vida pessoal.

\footnotetext{
52 DIAS, Maria Berenice. Manual de Direito das Famílias. $8^{\mathrm{a}}$ ed. São Paulo: Revista dos Tribunais, 2011. p. 63.
} 


\section{2 - Princípio da solidariedade familiar}

Sobre o princípio da solidariedade nas relações familiares, Madaleno discorre:

A solidariedade é principio e oxigênio de todas as relações familiares e afetivas, porque esses vínculos só podem se sustentar e se desenvolver em ambiente recíproco de compreensão e cooperação, ajudando-se mutuamente sempre que se fizer necessário. ${ }^{53}$

Esse princípio, que tem origem nos vínculos afetivos, dispõe de elevado conteúdo ético e moral, uma vez que contém em suas entranhas o próprio significado da expressão solidariedade, que compreende a fraternidade e a reciprocidade. ${ }^{54}$

Dias assim leciona: "A pessoa só existe enquanto coexiste" e a "solidariedade é o que cada um deve ao outro". 55

Dessa forma, a solidariedade no núcleo familiar deve ser entendida como a solidariedade recíproca entre cônjuges e companheiros, quanto à assistência moral e material, e a solidariedade em relação aos filhos. Esta última traduzida na exigência da pessoa de ser cuidada até atingir a idade adulta, isto é de ser mantida, instruída e educada para sua plena formação social. $^{56}$

A regra matriz do principio da solidariedade é o inciso I do artigo $3^{\circ}$ da Constituição Federal. Contudo, as regras que são de maior importância para o presente trabalho, se revelam no dever dos pais de assistência aos filhos (artigo 229, CF) e no dever da família, da sociedade e do Estado na proteção da criança e do adolescente (artigo 227, CF).

\footnotetext{
${ }^{53}$ MADALENO, Rolf. Curso de Direito de Família. 4 a ed. Rio de Janeiro: Forense, 2011. p. 90.

${ }^{54}$ DIAS, Maria Berenice. Manual de Direito das Famílias. $8^{\mathrm{a}}$ ed. São Paulo: Revista dos Tribunais, 2011. p. 66.

55 Ibid. p. 66.

${ }^{56}$ LÔBO, Paulo Luiz Netto. Direito Civil: famílias. $4^{\text {a }}$ ed. São Paulo: Saraiva, 2011. p. 64.
} 
Ainda, a Convenção Internacional sobre os Direitos da Criança (ONU, 1989) e o Estatuto da Criança e do Adolescente incluem a solidariedade entre os princípios a serem observados. ${ }^{57}$

\title{
2.3 - Princípio da convivência familiar
}

\author{
Nos ensina Lôbo:
}

A convivência familiar é a relação afetiva diuturna e duradoura entretecida pelas pessoas que compõem o grupo familiar, em virtude de laços de parentesco ou não, no ambiente comum. Supõe o espaço físico, a casa, o lar, a moradia, mas não necessariamente, [...]. É o ninho no qual as pessoas se sentem recíproca e solidariamente acolhidas e protegidas, especialmente as crianças. ${ }^{58}$

A Constituição Federal traz explicitamente tal princípio no artigo 227, que trata dentre os deveres da família, da sociedade e do Estado, o dever de assegurar à criança e ao adolescente o direito à convivência familiar e comunitária.

Ainda, a Convenção Internacional sobre os Direitos da Criança de 1989, em seu artigo 93, estabelece que, no caso de pais separados, a criança tem o direito de "manter regularmente relações pessoais e contato direto com ambos, a menos que isso seja contrário ao interesse maior da criança". 59

Na mesma linha, Eliana Riberti Nazareth discorre:

Em outra oportunidade assinalei a necessidade de modificação da prática e do conceito de "direito de visitas" para "direito-dever de convivência". Pais e filhos precisam desfrutar da convivência mútua com tudo o que isso tem de bom e de ruim, com suas vantagens e inconvenientes. ${ }^{60}$

\footnotetext{
${ }^{57}$ LÔBO, Paulo Luiz Netto. Direito Civil: famílias. $4^{\text {a }}$ ed. São Paulo: Saraiva, 2011. p. 64.

58 Ibid. p. 74.

${ }^{59}$ Ibid. p. 74.

${ }^{60}$ NAZARETH, Eliana Riberti. Guarda ou responsabilidade parental? Direito de visitas ou Direito à convivência?. In: PEREIRA, Tânia da Silva; PEREIRA, Rodrigo Cunha (Coords.). A ética da convivência familiar e sua efetividade no cotidiano dos tribunais. Rio de Janeiro: Forense, 2006. p. 210-211.
} 
Prossegue a autora e psicanalista:

Tem sido relatado pela literatura, salvo indicações em contrário que dizem respeito à presença de severas patologias psicológicas dos genitores, que toda criança precisa e deve ter, para seu adequado desenvolvimento psicossocial, um convívio regular, estável e próximo com os genitores, ainda que um deles não detenha a guarda. ${ }^{61}$

Sendo assim, conviver pressupõe basicamente interagir, criar vínculos, superar obstáculos, enfrentar desafios, trocar experiências ${ }^{62}$. E como já dito, esses fatores são essências na vida e desenvolvimento da criança e do adolescente, sendo determinantes na construção da identidade pessoal de cada indivíduo.

\section{4 - Princípios da prioridade absoluta, do melhor interesse da criança e da proteção integral}

O princípio da prioridade absoluta vem disciplinado tanto na Constituição Federal em seu artigo 227, como na Convenção Internacional sobre os Direitos da Criança e no Estatuto da Criança e do Adolescente, e significa que os menores de 18 anos devem ter seus direitos e garantias assegurados pela família, pela sociedade e pelo Estado com absoluta prioridade.

Como já se viu no início do presente trabalho, houve uma grande inversão de prioridades nas relações entre pais e filhos. Antes, o pátrio poder existia em função do pai, agora o poder familiar existe em função e no interesse do filho. ${ }^{63}$

\footnotetext{
${ }^{61}$ NAZARETH, Eliana Riberti. Guarda ou responsabilidade parental? Direito de visitas ou Direito à convivência?. In: PEREIRA, Tânia da Silva; PEREIRA, Rodrigo Cunha (Coords.). A ética da convivência familiar e sua efetividade no cotidiano dos tribunais. Rio de Janeiro: Forense, 2006. p. 210-211.

${ }^{62}$ NOVAES, Maria Helena. A convivência entre as gerações e o contexto sociocultural. In: PEREIRA, Tânia da Silva; PEREIRA, Rodrigo Cunha (Coords.). A ética da convivência familiar e sua efetividade no cotidiano dos tribunais. Rio de Janeiro: Forense, 2006. p. 215.

${ }^{63}$ LÔBO, Paulo Luiz Netto. Direito Civil: famílias. $4^{\text {a }}$ ed. São Paulo: Saraiva, 2011. p. 75.
} 
Diante disso, outro importante principio é o do melhor interesse da criança, que preconiza a ideia de que qualquer decisão deve ser tomada considerando o seu melhor interesse. Tal principio parte da ideia de ser a criança e o adolescente sujeitos de direitos, como pessoas em condição peculiar de desenvolvimento e merecedores de integral proteção. ${ }^{64}$

Ressalte-se que a proteção dos direitos da criança e dos adolescentes ganhou status de direito fundamental através da Convenção Internacional sobre os Direitos da Criança, que se tornou lei interna com o Decreto n. 99.770 de 1990.

Conforme ensina Madaleno, crianças e adolescentes são destinatários do principio do melhor interesse, conceito jurídico que é indeterminado, mas que sempre deverá prevalecer em favor do menor quando em confronto com outros valores, uma vez que sempre será necessário assegurar o pleno desenvolvimento físico e mental desse adulto do futuro, sujeito de direitos. ${ }^{65}$

A grande vulnerabilidade e fragilidade em que se encontram as crianças e os adolescentes, considerados pessoas em desenvolvimento, faz com que sejam destinatários desse tratamento especial, daí a consagração, em favor desses menores, do princípio do melhor interesse e da doutrina da proteção integral. $^{66}$

Vale transcrever o artigo $1^{\circ}$ e $3^{\circ}$ do ECA:

Art. $1^{\circ}$. Esta Lei dispõe sobre a proteção integral à criança e ao adolescente.

Art. $3^{\circ}$. A criança e o adolescente gozam de todos os direitos fundamentais inerentes à pessoa humana, sem prejuízo da proteção integral de que trata esta Lei, assegurando-se-lhes, por lei ou por outros meios, todas as oportunidades e facilidades, a fim de lhes facultar o desenvolvimento físico, mental, moral, espiritual e social, em condições de liberdade e de dignidade.

\footnotetext{
${ }^{64}$ LÔBO, Paulo Luiz Netto. Direito Civil: famílias. $4^{\mathrm{a}}$ ed. São Paulo: Saraiva, 2011. p. 75.

${ }^{65}$ MADALENO, Rolf. Curso de Direito de Família. $4^{\mathrm{a}}$ ed. Rio de Janeiro: Forense, 2011. p. 5152.

${ }^{66}$ DIAS, Maria Berenice. Manual de Direito das Famílias. $8^{\mathrm{a}}$ ed. São Paulo: Revista dos Tribunais, 2011. p. 68.
} 


\section{5 - Princípio da afetividade}

Tal princípio está implícito na Constituição Federal, mas segundo Lôbo, podem ser encontrados quatro fundamentos essenciais do princípio da afetividade: a) todos os filhos são iguais, independentemente de sua origem (artigo 227, § $6^{\circ}, \mathrm{CF}$ ); b) a adoção como escolha afetiva e com igualdade de direitos (artigo 227, $\S \S 5^{\circ}$ e $6^{\circ}, \mathrm{CF}$ ); c) a comunidade formada por qualquer dos pais e seus descendentes, incluindo os adotivos, possuindo a mesma dignidade de família constitucionalmente protegida (artigo 226, § $\left.4^{\circ}, \mathrm{CF}\right)$; d) a convivência familiar como prioridade absoluta assegurada à criança e ao adolescente (artigo 227, CF). ${ }^{67}$

Como se nota, o reconhecimento de outros modelos de entidades familiares, e não somente aquela constituída pelo casamento, o fim da discriminação entre filhos, a elevação ao mesmo grau de igualdade dos filhos naturais ou adotivos, demonstram o grande espaço que o afeto vem adquirindo no ordenamento jurídico brasileiro.

Sobre a afetividade Madaleno comenta:

O afeto é a mola propulsora dos laços familiares e das relações interpessoais movidas pelo sentimento e pelo amor, para ao fim e ao cabo dar sentido e dignidade à existência humana. A afetividade deve estar presente nos vínculos de filiação e de parentesco, variando tão somente na sua intensidade e nas especificidades do caso concreto. Necessariamente os vínculos consanguíneos não se sobrepõem aos liames afetivos, podendo até ser afirmada a prevalência desses sobre aqueles. ${ }^{68}$

Nessa linha, Dias ensina que o afeto não é fruto da biologia, pelo contrário, os laços de afeto e de solidariedade derivam da convivência familiar e não do sangue. ${ }^{69}$

A sobrevivência humana depende, e muito, da interação do afeto, uma vez que este é valor supremo, de grande necessidade, bastando apenas

\footnotetext{
${ }^{67}$ LÔBO, Paulo Luiz Netto. Direito Civil: famílias. $4^{\text {a }}$ ed. São Paulo: Saraiva, 2011. p. 71.

${ }^{68}$ MADALENO, Rolf. Curso de Direito de Família. $4^{\mathrm{a}}$ ed. Rio de Janeiro: Forense, 2011. p. 95.

${ }^{69}$ DIAS, Maria Berenice. Manual de Direito das Famílias. $8^{\text {a }}$ ed. São Paulo: Revista dos Tribunais, 2011. p. 71.
} 
atentar para as demandas que estão surgindo para apurar a responsabilidade civil pela ausência de afeto. ${ }^{70}$

Sendo assim, diante do crescente número de demandas tratando do abandono afetivo, mister se faz analisar a importância que o afeto e o cuidado vêm adquirindo como valores jurídicos, e é o que se fará a partir desse momento.

\subsection{1 - O afeto e o cuidado como valores jurídicos}

Como já explicitado, a família, com o passar dos anos sofreu significativas transformações, adquirindo um novo perfil, voltado muito mais a realizar os interesses afetivos e existenciais de seus integrantes. Dessa maneira, na esteira dessa evolução, o direito de família instalou uma nova ordem jurídica para a família, atribuindo valor jurídico significativo ao afeto. ${ }^{71}$

Conforme sustenta Tânia Pereira:

A proteção da criança e do adolescente envolve princípios que se destacam, a cada dia, como valores jurídicos. A família contemporânea tem priorizado relações de afeto, solidariedade e responsabilidade, abandonando a sua identificação tradicional como núcleo econômico e de reprodução. ${ }^{72}$

O mesmo acontece com a ideia de cuidado, que cada vez mais ganha a conotação de valor jurídico. Conforme ensina Lôbo:

Desenvolve-se no âmbito do direito de família estudos relativos ao "cuidado como valor jurídico". O cuidado desponta com força nos estatutos tutelares das pessoas vulneráveis, como a criança e o idoso, que regulamentaram os comandos constitucionais sobre a matéria. O cuidado, sob o ponto de vista do direito, recebe

\footnotetext{
${ }^{70}$ MADALENO, Rolf. Curso de Direito de Família. $4^{\text {a }}$ ed. Rio de Janeiro: Forense, 2011. p. 9596.

${ }^{71}$ DIAS, Maria Berenice. Manual de Direito das Famílias. $8^{\mathrm{a}}$ ed. São Paulo: Revista dos Tribunais, 2011. p. 71.

${ }^{72}$ PEREIRA, Tânia da Silvia. O cuidado como valor jurídico. In: PEREIRA, Tânia da Silva; PEREIRA, Rodrigo Cunha (Coords.). A ética da convivência familiar e sua efetividade no cotidiano dos tribunais. Rio de Janeiro: Forense, 2006. p. 232.
} 
a força subjacente do principio da solidariedade, como expressão particularizada desta. $^{73}$

A importância do afeto e do cuidado nasce em virtude da proteção que os vulneráveis, entres estes crianças e adolescentes, recebem do ordenamento jurídico atual. Já é sabido e comprovado por diversos estudos sociais que, para obter um desenvolvimento saudável e pleno, a presença de relações afetivas e de cuidado são essenciais.

A formação da personalidade de cada indivíduo, desde o seu nascimento, depende em grande parte do recebimento de afeto e cuidado por parte de seus ascendentes. A criança e o adolescente precisam receber e dar afeto para se tornarem seres humanos integrais, isto é, tratá-los com afeto, cuidado e respeito, servirá de estímulo e ajuda para suportar e enfrentar as dificuldades da vida. ${ }^{74}$

Ainda, a falta de afeto e de cuidado faz surgir crianças tristes e adolescentes revoltados, que se mostram rebeldes, indisciplinados, ou simplesmente incapazes de agir com serenidade e segurança. ${ }^{75}$ Dessa forma, a falta de tais valores na vida de um ser em formação traz consequências negativas para o próprio ser humano e, ainda, para a sociedade ao seu redor, já que jovens rebeldes e indisciplinados podem gerar o aumento de uma delinquência juvenil.

Acerca do valor que o afeto possui nas relações parentais, Tânia Pereira o considera como o diferencial que define uma entidade familiar, consistindo no sentimento entre duas ou mais pessoas que se afeiçoam pelo convívio diuturno, em virtude de uma origem ou de um destino comum. ${ }^{76}$ Desse modo, o princípio da afetividade, tão citado atualmente, já faz parte do direito brasileiro, que toma sempre por base as relações afetivas entre os membros de uma entidade familiar.

\footnotetext{
${ }^{73}$ LÔBO, Paulo Luiz Netto. Direito Civil: famílias. $4^{\text {a }}$ ed. São Paulo: Saraiva, 2011. p. 65.

${ }^{74}$ PEREIRA, Tânia da Silvia. O cuidado como valor jurídico. In: PEREIRA, Tânia da Silva; PEREIRA, Rodrigo Cunha (Coords.). A ética da convivência familiar e sua efetividade no cotidiano dos tribunais. Rio de Janeiro: Forense, 2006. p. 234.

${ }^{75}$ Ibid. p. 234.

${ }^{76}$ Ibid. p. 236.
} 
Quanto ao cuidado, desde que a Convenção Internacional sobre os Direitos da Criança foi ratificada pelo Brasil, o cuidado como valor jurídico ganhou bases constitucionais. Segundo retrata Tânia Pereira, a Convenção, em seu artigo $3^{\circ}$, indica que "os Estados Partes se certificarão que as instituições, os serviços e os estabelecimentos encarregados do cuidado ou da direção das crianças cumpram com os padrões estabelecidos pelas autoridades competentes", e ainda, o artigo $7^{\circ}$, assegura à criança "o direito de conhecer seus pais e a ser cuidada por eles", sendo esses direitos recebidos pelo artigo $5^{\circ}, \S 2^{\circ}$ da $\mathrm{CF}$, como direitos fundamentais. ${ }^{77}$

Assim, o valor que o cuidado tem nas relações familiares já vem sendo muito citado nas doutrinas e jurisprudências. A título de exemplo, em importante decisão recente do Superior Tribunal de Justiça sobre o abandono afetivo, julgada em 24/04/2012, a Ministra Nancy Andrighi assim afirmou:

O desvelo e atenção à prole não podem mais ser tratados como acessórios no processo de criação, porque, há muito, deixou de ser intuitivo que o cuidado, vislumbrado em suas diversas manifestações psicológicas, não é apenas um fator importante, mas essencial à criação e formação de um adulto que tenha integridade física e psicológica e seja capaz de conviver, em sociedade, respeitando seus limites, buscando seus direitos, exercendo plenamente sua cidadania. $^{78}$

Ainda, prossegue a Ministra:

Essa percepção do cuidado como tendo valor jurídico já foi, inclusive, incorporada em nosso ordenamento jurídico, não com essa expressão, mas com locuções e termos que manifestam suas diversas desinências, como se observa do artigo 227 da $\mathrm{CF} / 88$. $^{79}$

Portanto, o afeto e o cuidado, ao receberem referências implícitas em todo o ordenamento brasileiro como sendo deveres dos pais em relação aos

\footnotetext{
${ }^{77}$ Ibid. p. 231.

${ }^{78}$ STJ, Recurso Especial n. 1159242/SP (2009/0193701-9), Rel. Min. Nancy Andrighi, Terceira Turma, Brasília, julgado em 24 de abril de 2012.

${ }^{79}$ STJ, Recurso Especial n. 1159242/SP (2009/0193701-9), Rel. Min. Nancy Andrighi, Terceira Turma, Brasília, julgado em 24 de abril de 2012.
} 
filhos, são traduzidos como importantes valores jurídicos protegidos pelo direito pátrio.

Desse modo, a falta de afeto e o descuido dos pais estão sendo cada vez mais questionados nos tribunais brasileiros como sendo causadores de responsabilização civil dos pais. Ressalte-se que este é o objetivo central do presente trabalho, analisar o cabimento ou não de danos morais por abandono afetivo, e, então, a partir do próximo capítulo adentraremos ao estudo da responsabilidade civil. 


\section{CAPÍTULO 3 - RESPONSABILIDADE CIVIL}

\section{1 - Conceito e finalidade}

Primeiramente vale ressaltar que o vocábulo "responsabilidade" advém do verbo latino respondere, designando o fato de alguém ter se constituído garantidor de algo. ${ }^{80}$

Segundo Cavalieri Filho, em seu sentido etimológico, a palavra responsabilidade exprime a ideia de obrigação, encargo, contraprestação. E em seu sentido jurídico, o vocábulo possui a mesma ideia, designando o dever que alguém tem de reparar o prejuízo que surgiu pela violação de um outro dever. ${ }^{81}$

Assim sintetiza: "responsabilidade civil é um dever jurídico sucessivo que surge para recompor o dano decorrente da violação de um dever jurídico originário." ${ }^{82}$

E dessa forma, o dever jurídico originário seria uma ordem ou comando imposto pelo ordenamento aos indivíduos, visando manter uma ordem social, e o dever jurídico sucessivo a necessidade de reparação do dever jurídico originário violado, visando obter novamente o equilíbrio social rompido.

Venosa ensina que o termo responsabilidade é utilizado em qualquer situação na qual uma pessoa deva arcar com as consequências de um ato, fato, ou negócio danoso, ou seja, sob essa noção, toda atividade humana pode acarretar o dever de indenizar. ${ }^{83}$

Nessa mesma linha Diniz conceitua:

A reponsabilidade civil é a aplicação de medidas que obriguem uma pessoa a reparar dano moral ou patrimonial causado a terceiros, em razão de ato por ela

\footnotetext{
${ }^{80}$ DINIZ, Maria Helena. Curso de direito civil brasileiro: responsabilidade civil. Volume 7. $17^{\mathrm{a}}$ ed. São Paulo: Saraiva, 2003. p. 35.

${ }^{81}$ FILHO, Sérgio Cavalieri. Programa de responsabilidade civil. $6^{\mathrm{a}}$ ed. São Paulo: Malheiros, 2005. p. 24.

${ }^{82}$ Ibid. p. 24.

${ }^{83}$ VENOSA, Sílvio de Salvo. Direito Civil: Responsabilidade civil. $5^{a}$ ed. São Paulo: Atlas, 2005. p. 13.
} 
mesma praticado, por pessoa por quem ela responde, por alguma coisa a ela pertencente ou de simples imposição legal. ${ }^{84}$

Portanto, o dano causado por um ato ilícito rompe o equilíbrio jurídico-econômico que existia entre o agente e a vítima e, com isso, surge uma necessidade de se restabelecer esse equilíbrio, o que se faz recolocando o prejudicado no status quo ante, buscando o mais elementar sentimento de justiça. $^{85}$

Trataremos neste estudo a chamada responsabilidade civil subjetiva, que possui fundamento nos artigos 186 e 927 do Código Civil, que assim dispõem:

Art. 186. Aquele que, por ação ou omissão voluntária, negligência ou imperícia, violar direito e causar dano a outrem, ainda que exclusivamente moral, comete ato ilícito.

Art. 927. Aquele que, por ato ilícito (arts. 186 e 187), causar dano a outrem, fica obrigado a repará-lo.

Dessa forma, a responsabilidade civil se baseia na obrigação de reparar um dano, seja moral ou patrimonial, causado à terceiro, recolocando este na situação em que se encontrava antes do dano sofrido.

\section{2 - Pressupostos da responsabilidade civil subjetiva}

A doutrina, analisando a literalidade do artigo 186 do CC, normalmente aponta quatro pressupostos da responsabilidade civil. $\mathrm{O}$ $\operatorname{artigo~}^{86}$ dispõe que a pessoa que violar direito ou causar dano a outrem, por ação ou omissão voluntária, negligência ou imprudência, comete ato ilícito e, portanto, é obrigado a reparar.

\footnotetext{
${ }^{84}$ DINIZ, Maria Helena. Curso de direito civil brasileiro: responsabilidade civil. Volume 7. $17^{\mathrm{a}}$ ed. São Paulo: Saraiva, 2003. p. 35.

${ }^{85}$ FILHO, Sérgio Cavalieri. Programa de responsabilidade civil. $6^{a}$ ed. São Paulo: Malheiros, 2005.p. 36.

86 “Art. 186. Aquele que, por ação ou omissão voluntária, negligência ou imperícia, violar direito e causar dano a outrem, ainda que exclusivamente moral, comete ato ilícito"
} 
Sendo assim, pode-se concluir pelos quatro elementos essenciais da responsabilidade civil subjetiva, quais sejam: ação ou omissão, culpa ou dolo do agente, relação de causalidade, e o dano experimentado pela vítima. $^{87}$

Primeiramente, tem-se a conduta, ou seja, o comportamento humano voluntário que se exterioriza através de uma ação ou omissão do agente, produzindo consequências jurídicas. ${ }^{88}$

Em segundo lugar, a lei traz o dolo e a culpa do agente quando descreve: "ação ou omissão voluntária", referindo ao dolo, e "negligência ou imprudência", referindo a culpa. Nesse caso, o dolo consiste na vontade de se cometer uma violação de direito e a culpa consiste na falta de diligência. $^{89}$

Cavalieri traz a noção de culpa com um sentido amplo (lato sensu), ou seja, abrangendo toda espécie de comportamento contrário ao direito, seja intencional, como no caso de dolo, ou não, como na culpa. ${ }^{90}$

Assim ensina o ilustre desembargador:

A ideia da culpa está visceralmente ligada à responsabilidade, por isso que, de regra, ninguém pode merecer censura ou juízo de reprovação sem que tenha faltado com o dever de cautela em seu agir. Daí ser a culpa, de acordo com a teoria clássica, o principal pressuposto da responsabilidade civil subjetiva. ${ }^{91}$

Nessa mesma linha Diniz afirma:

No nosso ordenamento jurídico vigora a regra geral de que o dever ressarcitório pela prática de atos ilícitos decorre da culpa, ou seja, da reprovabilidade ou censurabilidade da conduta do agente. (...) $\mathrm{O}$ ato ilícito qualifica-se pela culpa. Não havendo culpa, não haverá, em regra, qualquer responsabilidade. ${ }^{92}$

\footnotetext{
${ }^{87}$ GONÇALVES, Carlos Roberto. Responsabilidade Civil. $9^{a}$ ed. São Paulo: Saraiva, 2005. p. 32.

${ }^{88}$ FILHO, Sérgio Cavalieri. Programa de responsabilidade civil. $6^{\mathrm{a}}$ ed. São Paulo: Malheiros, 2005. p. 48.

${ }^{89}$ GONÇALVES, Carlos Roberto. Op. cit., p. 33.

${ }^{90}$ FILHO, Sérgio Cavalieri. Op. cit., p. 54.

${ }^{91}$ Ibid. p. 39.

92 DINIZ, Maria Helena. Curso de direito civil brasileiro: responsabilidade civil. Volume 7. $17^{\mathrm{a}}$ ed. São Paulo: Saraiva, 2003. p. 40.
} 
Em terceiro lugar, tem-se a relação de causalidade, expressa pelo verbo "causar" do artigo 186 citado e é a relação de causa e efeito entre a ação ou omissão do agente e o dano verificado. ${ }^{93}$

Segundo Diniz, essa relação, também chamada de nexo causal é o vínculo entre o prejuízo e a ação, de modo que o fato lesivo deverá ser oriundo da ação, diretamente ou como sua consequência previsível. Ou seja, o fato poderá não ser a causa imediata, mas se for condição para a produção do dano, o agente responderá pela consequência. ${ }^{94}$

Por outro lado, se acontecer o dano, mas sua causa não estiver relacionada com o comportamento do agente, inexistirá relação de causalidade e tampouco a obrigação de indenizar. ${ }^{95}$

Ressalta-se, portanto, que existem algumas excludentes da responsabilidade civil e, nesses casos, algum fator interfere no acontecimento e rompe o nexo de causalidade, excluindo a responsabilidade do agente. São exemplos: a legítima defesa, o estado de necessidade, o ato de terceiro, a culpa exclusiva da vítima, caso fortuito, prescrição, dentre outros.

Por fim, o dano. Conforme assinala Cavalieri Filho, não haveria que se falar em indenização, nem em ressarcimento, se não houvesse dano. Não pode haver responsabilidade sem dano. ${ }^{96}$

Diniz define o dano como a lesão (diminuição ou destruição) que, em decorrência de um certo evento, uma pessoa sofre, contra sua vontade, em qualquer bem ou interesse jurídico, patrimonial ou moral. ${ }^{97}$

O dano pode ser material, também chamado de patrimonial, ou moral, logo, extrapatrimonial. A seguir adentramos mais especificamente no estudo do dano moral.

\footnotetext{
${ }^{93}$ GONÇALVES, Carlos Roberto. Responsabilidade Civil. $9^{\text {a }}$ ed. São Paulo: Saraiva, 2005. p. 33.

${ }^{94}$ DINIZ, Maria Helena. Curso de direito civil brasileiro: responsabilidade civil. Volume 7. $17^{\mathrm{a}}$ ed. São Paulo: Saraiva, 2003. p. 100.

${ }^{95}$ GONÇALVES, Carlos Roberto. Op. cit., p. 33.

${ }^{96}$ FILHO, Sérgio Cavalieri. Programa de responsabilidade civil. $6^{\mathrm{a}}$ ed. São Paulo: Malheiros, 2005. p. 95.

${ }^{97}$ DINIZ, Maria Helena. Op. cit., p. 61.
} 


\section{3 - Dano moral}

O ponto de partida se coloca em saber o que vem a ser o dano moral. Nesse ponto a doutrina apresenta diversos conceitos. Alguns simplesmente dizem que dano moral é aquele que não tem caráter patrimonial, ou seja, é todo dano não-material, e, por outro lado, outros preferem definir como uma lesão de um bem integrante da personalidade. ${ }^{98}$

Apesar das distinções doutrinárias, Moraes ensina que:

Doutrina e a jurisprudência dominantes têm como adquirido que o dano moral é aquele que, independentemente de prejuízo material, fere direitos personalíssimos, isto é, todo e qualquer atributo que individualiza cada pessoa. [...] O dano é ainda considerado moral quando os efeitos da ação, embora não repercutam na órbita de seu patrimônio material, originam angústia, dor, sofrimento, tristeza ou humilhação à vítima, trazendo-lhe sensações e emoções negativas. ${ }^{99}$

Nessa linha, Cahali afirma:

Na realidade, multifacetário o ser anímico, tudo aquilo que molesta gravemente a alma humana, ferindo-lhe gravemente os valores fundamentais inerentes à sua personalidade ou reconhecidos pela sociedade em que está integrado, qualificase, em linha de princípio, como dano moral; ${ }^{100}$

Prossegue o autor:

não há como enumerá-los exaustivamente, evidenciando-se na dor, na angústia, no sofrimento, na tristeza pela ausência de um ente querido falecido; no desprestígio, na desconsideração social, no descrédito a reputação, na humilhação pública, no devassamento da privacidade; no desequilíbrio da normalidade psíquica, nos traumatismos emocionais, na depressão ou no desgaste psicológico, nas situações de constrangimento moral. ${ }^{101}$

Dessa forma, é sabido que o ato lesivo pode afetar a personalidade do individuo e seus direitos mais íntimos, como a honra, a integridade

\footnotetext{
${ }^{98}$ FILHO, Sérgio Cavalieri. Programa de responsabilidade civil. $6^{a}$ ed. São Paulo: Malheiros, 2005. p. 100.

${ }^{99}$ MORAES, Maria Celina Bodin de. Danos à pessoa humana: uma leitura civil-constitucional dos danos morais. Rio de Janeiro: Renovar, 2003. p. 157.

${ }^{100}$ CAHALI, Yussef Said. Dano moral. $3^{\mathrm{a}}$ ed. São Paulo: Revista dos Tribunais, 2005. p. 22-23.

${ }^{101}$ Ibid. p. 22-23.
} 
psíquica, a intimidade, a liberdade, a imagem e os próprios sentimentos afetivos.

$\mathrm{Na}$ visão de Cavalieri, todos esses direitos estariam englobados em um direito maior, que é o direito à dignidade, já que a dignidade humana nada mais é do que a base de todos os valores morais e a essência de todos os direitos personalíssimos. Segundo o autor, portanto, "dano moral, à luz da Constituição vigente, nada mais é do que violação do direito à dignidade". ${ }^{102}$

Esse dano gerado, denominado dano moral, obviamente deverá ser compensado por seu causador. Passível a doutrina e a jurisprudência atuais neste sentido.

Destaca-se alguns dispositivos importantes do ordenamento jurídico que tratam do dano moral, como o artigo $5^{\circ}$, incisos $\mathrm{V}$ e $\mathrm{X}$ da $\mathrm{CF}$ e o artigo 186 do CC:

Art. $5^{\circ} .[\ldots]$

V. é assegurado o direito de resposta, proporcional ao agravo, além da indenização por dano material, moral ou à imagem;

$X$. são invioláveis a intimidade, a vida privada, a honra e a imagem das pessoas, assegurado o direito a indenização pelo dano material ou moral decorrente de sua violação;

Art. 186. Aquele que, por ação ou omissão voluntária, negligência ou imperícia, violar direito e causar dano a outrem, ainda que exclusivamente moral, comete ato ilícito.

Entretanto, apesar da reparabilidade do dano moral já estar inserida no direito brasileiro, não se pode permitir abusos e excessos nas ações indenizatórias, uma vez que meros dissabores do dia a dia não caracterizam o dano moral. Sobre isso ensina Cavalieri:

Só deve ser reputado como dano moral a dor, vexame, sofrimento ou humilhação que, fugindo à normalidade, interfira intensamente no comportamento psicológico do individuo, causando-lhe aflições, angústia e desequilíbrio em seu bem-estar. Mero dissabor, aborrecimento, mágoa, irritação ou sensibilidade exacerbada estão fora da órbita do dano moral, porquanto, além de fazerem parte

\footnotetext{
${ }^{102}$ FILHO, Sérgio Cavalieri. Programa de responsabilidade civil. $6^{\text {a }}$ ed. São Paulo: Malheiros, 2005. p. 101.
} 
da normalidade do nosso dia-a-dia, no trabalho, no trânsito, entre amigos e até no ambiente familiar, tais situações não são intensas e duradouras, a ponto de romper o equilíbrio psicológico do individuo. Se assim não se entender, acabaremos por banalizar o dano moral, ensejando ações judiciais em busca de indenizações pelos mais triviais aborrecimentos. ${ }^{103}$

$\mathrm{O}$ dano moral pode ser dividido em direto ou indireto. $\mathrm{O}$ dano direto é aquele que consiste na lesão de um interesse que visa a satisfação de um bem jurídico extrapatrimonial, contido nos direitos da personalidade ou nos atributos da pessoa, já o indireto é aquele que traz um prejuízo a um interesse extrapatrimonial, devido a uma lesão a um bem patrimonial. ${ }^{104}$

Segundo Gonçalves, a prova do dano moral, salvo em casos especiais, é dispensada, pois se passa no interior da personalidade. Trata-se de presunção absoluta na grande maioria dos casos, por exemplo, não precisa a mãe comprovar que sentiu a morte do filho. ${ }^{105}$

Contudo, nesses casos, apesar de haver uma presunção absoluta do sofrimento em si, a vítima deverá provar que o dano sofrido tem nexo causal com a conduta culposa do agente.

Ainda, por outro lado, existem situações peculiares que exigem provas para demonstração do dano moral, como por exemplo, uma prova pericial para comprovar o mal sofrido. Obviamente essa análise de provas vai variar caso a caso.

Quanto a natureza jurídica da reparação do dano moral, tem prevalecido o entendimento de que a sua reparação pecuniária tem duplo caráter: compensatório para a vítima e punitivo para o ofensor. Ou seja, ao mesmo tempo que serve de consolo, uma espécie de compensação para atenuação do sofrimento da vítima, também atua como sanção ao causador do dano. ${ }^{106}$

Ainda, existem autores que vão trazer o caráter preventivo da reparação por dano moral, uma vez que esta vai atuar como fator preventivo

\footnotetext{
${ }^{103}$ Ibid. p. 105.

${ }^{104}$ GONÇALVES, Carlos Roberto. Responsabilidade Civil. 9a ed. São Paulo: Saraiva, 2005. p. 566.

${ }^{105}$ Ibid. p. 570.

${ }^{106}$ Ibid. p. 584.
} 
de outros atos iguais ou parecidos com o ato lesivo. Ou seja, a reparação vai servir de exemplo para a sociedade desestimulando outras pessoas de agirem da mesma forma.

\subsection{1 - Quantificação do dano moral}

Em se tratando de dano moral, um dos maiores problemas encontrados no dia a dia dos tribunais brasileiros é a dificuldade na quantificação desse dano.

Conforme assevera Gonçalves:

O problema da quantificação do dano moral tem preocupado o mundo jurídico, em virtude da proliferação de demandas, sem que existam parâmetros seguros para a sua estimação. Enquanto o ressarcimento do dano material procura colocar a vítima no estado anterior, [...] a reparação do dano moral objetiva apenas uma compensação, um consolo, sem mensurar a dor. Em todas as demandas que envolvem danos morais, o juiz defronta-se com o mesmo problema: a perplexidade ante a inexistência de critérios uniformes e definidos para arbitrar um valor adequado. ${ }^{107}$

Venosa explica que o dano moral é o prejuízo que afeta o ânimo psíquico, moral e intelectual da vítima, ou seja, sua atuação é dentro dos direitos da personalidade. Nesse meio, o prejuízo transita pelo imponderável, e por isso que aumentam as dificuldades de se estabelecer a justa recompensa pelo dano. ${ }^{108}$

Uma parte da doutrina entende que a fixação da reparação por danos morais deve ser feita por arbitramento do juiz, enquanto outra parte entende que seria necessário a fixação de critérios definidos para fixar o quantum indenizatório.

Bernardo, em seu livro "Dano moral: critérios de fixação de valor" expõe que, após diversas pesquisas na doutrina e na jurisprudência, verificou que existem três grupos de critérios de valoração dos danos

\footnotetext{
${ }^{107}$ Ibid. p. 586.

${ }^{108}$ VENOSA, Sílvio de Salvo. Direito Civil: Responsabilidade civil. $5^{\text {a }}$ ed. São Paulo: Atlas, 2005. p. 47.
} 
morais, que são: a) os critérios matemáticos, vinculados ora com a pena criminal do ato ilícito, ora com os danos materiais; b) o tabelamento, pelo qual condutas danosas são classificadas e a indenização corresponderia a valores mínimo e máximos já previamente estabelecidos; c) o arbitramento judicial, que, por sua vez, é o arbítrio do próprio julgador seguindo uma série de fatores. ${ }^{109}$

Apesar das diferentes tentativas para quantificar o dano moral, entende-se majoritariamente que não há outro meio mais eficaz que o arbitramento judicial. Meio este predominante na maioria dos tribunais do Brasil.

\section{Conforme explica Diniz:}

Na liquidação judicial, o magistrado tem, ante a fluidez e a subjetividade do sofrimento, o dever de apurar, com seu prudente arbítrio, os critérios a serem seguidos e o quantum debeatur, tendo por standard o homem médio na sociedade ao examinar a gravidade do fato e a dimensão do dano moral ocorrido e ao ponderar os elementos probatórios. ${ }^{110}$

Reis traz alguns elementos que devem sopesar na formação da decisão do juiz quando da fixação do quantum indenizatório, como: situação econômica, social, religiosa e cultural da vítima e do lesionador, grau de culpa, divulgação do fato, repercussão no meio social, entre outros. $^{111}$

Portanto, no Brasil, por não haver outra modalidade mais eficiente, a quantificação do dano moral é feita por arbitramento do juiz, que analisando o caso concreto e as características da vítima e do causador do dano, arbitrará o valor da indenização.

Vale lembrar que o juiz deve sempre agir na linha do bom senso, da moderação e da prudência, "tendo sempre em mente que se, por um lado, a

\footnotetext{
${ }^{109}$ BERNARDO, Wesley de Oliveira Louzada. Dano moral: critérios de fixação do valor. Rio de Janeiro: Renovar, 2005. p. 118.

${ }^{110}$ DINIZ, Maria Helena. Curso de direito civil brasileiro: responsabilidade civil. Volume 7. $17^{\mathrm{a}}$ ed. São Paulo: Saraiva, 2003. p. 95.

${ }^{111}$ REIS, Clayton. Dano moral. $4^{\text {a }}$ ed. Rio de Janeiro: Forense, 1998. p. 99.
} 
indenização deve ser a mais completa possível, por outro, não pode tornarse fonte de lucro indevido"112.

\subsection{2 - Dano moral nas relações familiares}

Tendo em vista as características peculiares das relações de família, que são baseadas no afeto, na moral e na ética, por muito tempo alguns autores sustentaram não ser cabível uma indenização por danos morais no âmbito familiar.

Sobre esse não cabimento, Moraes elucida:

De fato, a família, como é entendida atualmente, baseia-se muito mais na força do afeto do que em puros liames biológicos. Assim, "dano moral" e "direito de família" são expressões que em princípio se excluiriam e cuja combinação esboça um oximoro, quase um paradoxo. ${ }^{113}$

Isso porque os autores e aplicadores do direito entendiam que as relações familiares, baseadas no afeto, não poderiam ser resolvidas simplesmente pela aplicação da lei, uma vez que a norma não poderia abarcar todas as questões que tais relações podiam envolver, ou seja, não poderia mensurar todos os sentimentos envolvidos.

Ainda, por envolver sentimentos e relações íntimas, isto é, questões existenciais em geral, tratavam de valores que não podia-se mensurar, e sendo assim, seria impossível obter uma compensação.

Contudo, como já dito no presente texto as relações familiares sofreram mudanças, passando da família como instituição para famíliainstrumento, isto é, aquela que propicia um ambiente adequado ao desenvolvimento da personalidade de cada um de seus membros, o que

\footnotetext{
${ }^{112}$ FILHO, Sérgio Cavalieri. Programa de responsabilidade civil. $6^{\mathrm{a}}$ ed. São Paulo: Malheiros, 2005. p. 117.

${ }^{113}$ MORAES, Maria Celina Bodin de. Danos morais em família? Conjugalidade, parentalidade e responsabilidade civil. In: PEREIRA, Tânia da Silva; PEREIRA, Rodrigo Cunha (Coords.). A ética da convivência familiar e sua efetividade no cotidiano dos tribunais. Rio de Janeiro: Forense, 2006. p. 172.
} 
trouxe uma individualização e maior autonomia para as relações familiares. $^{114}$

E mais, com o avento da Constituição Federal de 1988 e a evidência do princípio da dignidade da pessoa humana, o ordenamento jurídico brasileiro passou a proteger o ser humano como sujeito de direitos, observando o lado da vítima e não deixando que esta, lesada em sua dignidade ou personalidade, fique sem ressarcimento.

Sendo assim, Moraes então explica que, neste novo ambiente, é possível perceber a união dos termos "dano moral e "direito de família". Entende a autora que a tendência individualista potencializa a autonomia privada nas relações, e tal autonomia, por outro lado, reduz os fatores que antes serviram a dificultar a imposição da responsabilidade civil entre familiares. $^{115}$

Sobre o cabimento da responsabilidade civil no direito de família, a Ministra Nancy Andrighi assim já decidiu:

Não existem restrições legais à aplicação das regras relativas à responsabilidade civil e o consequente dever de indenizar/compensar, no Direito de Família. Ao revés, os textos legais que regulam a matéria (art. $5^{\circ}, \mathrm{V}$ e X da CF e arts. $186 \mathrm{e}$ 927 do CC-02) tratam do tema de maneira ampla e irrestrita, de onde é possível se inferir que regulam, inclusive, as relações nascidas dentro de um núcleo familiar, em suas diversas formas. ${ }^{116}$

Ainda, sendo o ambiente familiar o local em que se dá a formação e o desenvolvimento da personalidade dos indivíduos, e sendo esta um direito garantido constitucionalmente, não há mais como dizer que a responsabilidade civil não abrange as relações familiares.

Portanto, as regras relativas à responsabilidade civil e aos danos morais podem sim ser aplicadas ao Direito de Família, visto que não existe qualquer restrição a essa aplicação.

\footnotetext{
${ }^{114}$ Ibid. p. 174.

${ }^{115}$ Ibid. p. 176.

${ }^{116}$ STJ, Recurso Especial n. 1159242/SP (2009/0193701-9), Rel. Min. Nancy Andrighi, Terceira Turma, Brasília, julgado em 24 de abril de 2012.
} 
Desse modo, ultrapassada a questão sobre o cabimento da responsabilidade civil nas relações familiares, no próximo capítulo adentramos ao tema central do trabalho, ou seja, analisaremos o cabimento de danos morais nas hipóteses de abandono afetivo. 


\section{CAPÍTULO 4 - DANO MORAL POR ABANDONO AFETIVO}

\section{1 - O abandono afetivo e suas hipóteses}

Como já foi bastante abordado no decorrer do presente texto, o direito de família atualmente trata muito mais de questões pessoais do que patrimoniais. A criança e o adolescente, como sujeitos de direito, ganharam importante papel dentro das relações familiares, nas quais um dos objetivos principais passa a ser garantir o seu melhor interesse.

Já frisamos a importância do afeto e do cuidado no desenvolvimento de seres humanos integrados socialmente e saudáveis psicologicamente. E, ainda, que tais valores são um dever dos pais e um direito dos filhos.

Acontece que, em diversas situações crianças e adolescentes vivenciam o abandono de seus pais. Algumas vezes o abandono material e afetivo, e outras vezes somente o afetivo. Vale ressaltar que pretendemos abordar a hipótese em que o pai abandona afetivamente seus filhos, não nos importando se este genitor contribui ou não materialmente com uma pensão alimentícia, ficando esta situação para outra análise, mas sim nos importa o fato de este ascendente negligenciar o afeto, educação e cuidado para com a prole.

Sobre o assunto Rodrigo Pereira dispôs:

No caso julgado pelo STJ em 2005, o abandono era apenas afetivo. O pai sempre pagou pensão alimentícia ao menor. Faltou alimento para a alma, afinal de contas, nem só de pão vive o homem. [...] A ausência de prestação de uma assistência material seria até compreensível, se se tratasse de um pai totalmente desprovido de recursos. Mas deixar de dar amor e afeto a um filho... não há razão nenhuma capaz de explicar tal falta. ${ }^{117}$

Sabemos que o abandono afetivo pode ocorrer por parte de qualquer um dos genitores, mas no intuito de facilitar o desenvolvimento do trabalho,

\footnotetext{
${ }^{117}$ PEREIRA Rodrigo da Cunha. Nem só de pão vive o Homem: Responsabilidade civil por abandono afetivo. Disponível em: <http://www.ibdfam.org.br/novosite/artigos/detalhe/392>. Acesso em 09 de outubro de 2012.
} 
optamos em restringi-lo somente à hipótese em que o pai abandona seus filhos, se ausentando e deixando de prestar assistência imaterial.

Com isso, não podemos deixar de apontar, apenas a título de exemplo, algumas possíveis situações que motivam e caracterizam esse abandono paterno.

Diferentes casos podem ser destacados, como aquele em que os genitores se divorciam e a guarda do filho é atribuída a mãe, enquanto o pai não se compromete com o desenvolvimento da criança, se fazendo ausente e "empurrando" para a genitora guardiã toda e qualquer responsabilidade e cuidado do filho.

Ou então, ainda nessa hipótese em que os pais se separam, quando há um direito de visita concedido ao pai e este se ausenta, não cumprindo seu dever, e direito do filho, aos períodos de visitação, deixando a criança frustrada em todas as suas expectativas quanto aos dias que iria passar com o mesmo.

Existem também os casos em que o pai constitui uma nova família, concebendo novos filhos, e largando ao total abandono o filho da relação anterior, justificando a constituição da nova família como uma forma de recomeçar a vida e esquecendo o filho que já possuía.

$\mathrm{Ou}$ a falta de preocupação do pai separado, que delega a genitora todo o dever de cuidar do filho sozinha, já que, por não residir com o filho, cria dificuldades inexistentes à manutenção de uma relação afetuosa. $\mathrm{Ou}$ também o genitor que decide se mudar para local distante, sem sequer procurar saber da vida do filho que deixou.

Ainda, um ambiente que é bastante cruel para essas crianças são as comemorações de datas festivas nas escolas, como o dia dos pais. Se o respectivo pai não comparece ao local, enquanto todos os amigos possuem a família completa ao redor, este momento é totalmente traumático na vida de um ser em desenvolvimento.

Dentre tantos casos de abandono, que não são exaustivos, deve-se sempre lembrar que o divórcio dos pais não pode acarretar a separação dos 
mesmos para com seus filhos, conforma ensina Giselda Hironaka, "a criança não se divorcia de seus pais"118. E assim também ressalta Nader, "a separação e o divórcio trazem a ruptura na vida do casal, não entre estes e os filhos" $" 119$.

Sobre o tema Dias reforça:

Viver em família é conviver com ambos os pais. O fim do relacionamento deles não pode prejudicar em nada o direito do filho ao cuidado de quem o ama. É necessário assegurar a formação da identidade e a construção da sua personalidade de forma plena. Certamente estes são os ingrediente indispensáveis para assegurar o direito fundamental à felicidade. Um direito de todos e de cada um! ${ }^{120}$

Sendo assim, poderíamos ficar eternamente listando as hipóteses em que se configuraria um abandono afetivo do genitor em relação aos filhos, mas o importante no presente estudo é analisar se estas hipóteses de abandono geram o dever de indenizar por parte do pai.

O nosso Código Penal atual disciplinou três situações de abandono, dentre os artigos 244 e 247, quando tratou dos crimes contra a família, que seriam: o abandono material, moral e intelectual.

Já o ECA, em seu artigo 249, trouxe a pena de multa para os pais que descumprirem, culposa ou dolosamente, os deveres inerentes ao poder familiar.

Contudo, não existe qualquer menção em todo o nosso ordenamento jurídico quanto ao abandono afetivo. Por mais que hoje em dia já se reconheça a importância do afeto como um valor jurídico e se considere o principio da afetividade como norteador das relações familiares, a palavra "afeto" não foi escrita pelo legislador em nenhuma lei brasileira e sequer na Constituição Federal.

\footnotetext{
${ }^{118}$ HIRONAKA Giselda Maria Fernandes Novaes. Os contornos jurídicos da responsabilidade afetiva na relação entre pais e filhos - além da obrigação legal de caráter material. Disponível em: 〈http://www.ibdfam.org.br/novosite/artigos/detalhe/289>. Acesso em 09 de outubro de 2012.

${ }^{119}$ NADER, Paulo. Curso de direito civil: Direito de família. Volume 5. $2^{\mathrm{a}}$ ed. Rio de Janeiro: Forense, 2008. p. 335.

120 DIAS, Maria Berenice. $O$ direito dos filhos a seus pais. Disponível em: $\langle$ http://www.mariaberenice.com.br/uploads/o_direito_dos_filhos_a_seus_pais.pdf $>$. Acesso em 10 de outubro de 2012.
} 
E é essa questão que vem sendo enfrentada frequentemente pela doutrina e pela jurisprudência, já que estão sendo surpreendidos com um número crescente de demandas acerca da possibilidade ou não de reparação civil por abandono afetivo.

Conforme se demonstrará mais a frente uma constante mudança de entendimentos vem acontecendo, e a doutrina majoritária e uma razoável parcela da jurisprudência já vêm considerando cabível tal reparação, inclusive em decisão recente da Terceira Turma do Superior Tribunal de Justiça.

A partir de agora, será analisada a aplicação dos elementos da responsabilidade civil aos casos de abandono afetivo.

\section{2 - Elementos da responsabilidade civil e sua aplicação ao abandono afetivo paterno}

\subsection{1 - Conduta omissiva quanto aos deveres paternos}

Primeiramente, vale chamar atenção para um importante pressuposto desse dever de indenizar, que seria a efetiva existência de uma relação paterno-filial, isto é, deve-se investigar se o genitor que se afastou de sua prole conhecia o fato de ser pai, uma vez que é improvável responsabilizar alguém por romper uma relação paterno-filial se a pessoa sequer conhecia sua condição de ascendente. ${ }^{121}$

Com isso, considerando a existência efetiva dessa relação paternofilial, destacam-se os deveres positivos que o pai deve ter com relação aos seus filhos. O artigo 227 da Constituição Federal, que já foi diversas vezes citado ao longo deste trabalho, atribuiu à família, à sociedade e ao Estado o

${ }^{121}$ HIRONAKA Giselda Maria Fernandes Novaes. Pressuposto, elementos e limites do dever de indenizar por abandono afetivo. In: PEREIRA, Tânia da Silva; PEREIRA, Rodrigo Cunha (Coords.). A ética da convivência familiar e sua efetividade no cotidiano dos tribunais. Rio de Janeiro: Forense, 2006. p. 134. 
dever de proteger a família, assegurando à criança e ao adolescente, com absoluta prioridade, diversos direitos. Além de colocá-los a salvo de toda forma de discriminação, exploração, violência e negligência.

Nesse sentido, Hironaka analisa e qualifica os direitos e deveres mais importantes que decorrem da relação paterno-filial e que são atribuíveis aos pais e filhos, concluindo que é preciso ser pai e mãe em sua amplitude legal, ou seja, exercendo os deveres de sustento, guarda e educação. $^{122}$

Quanto ao dever de sustento trata-se de uma questão patrimonial, em que os pais devem arcar com as necessidades dos filhos, colocando à disposição meios materiais suficientes para sustentá-los. Já quanto à guarda, esta se baseia no dever dos pais de manter os filhos em sua companhia. E quanto ao dever de educação, mais importante na presente pesquisa, os pais devem desempenhar as funções de educadores e autoridades para ajudar a formação da criança como pessoa. ${ }^{123}$

Os pais possuem deveres positivos, isto é, deveres de agir, com relação à sua prole, que também podem ser considerados como direitos dos filhos. Sendo assim, quando esse dever deixa de ser exercido, com a conduta omissiva do pai, configura-se uma situação de descuido e de abandono.

Nessa linha sustenta Hironaka,

O abandono afetivo se configura, desta forma, pela omissão dos pais, ou de um deles, pelo menos relativamente ao dever de educação, entendido este na sua acepção mais ampla, permeada de afeto, carinho, atenção, desvelo. Esta a fundamentação jurídica para que os pedidos sejam levados ao Poder Judiciário, na medida em que a Constituição Federal exige um tratamento primordial à criança e ao adolescente e atribui o correlato dever aos pais, à família, à comunidade e à sociedade. ${ }^{124}$

O genitor que não cumprir com seus deveres, isto é, não demonstrar afeto, carinho, atenção e, principalmente, cuidado em favor de sua prole,

\footnotetext{
${ }^{122}$ Ibid. p. 135.

${ }^{123}$ Ibid. p. 135-136.

${ }^{124}$ Ibid. p. 136.
} 
está desrespeitando um dever moral que lhe foi imposto, indo contra os princípios e direitos trazidos pela própria Constituição Federal.

Segundo Lôbo, a afetividade é dever imposto aos pais na sua relação com os filhos, ainda que exista desamor ou desafeição entre eles, ou seja, é um dever jurídico permanente oponível a pais e filhos, independentemente dos sentimentos que estes nutrem entre si. ${ }^{125}$

Dessa forma, a conduta do pai, de forma omissiva, se faz presente através de atitudes deliberadas de abandono do próprio filho, deixando de lhe prestar assistência imaterial, seja porque descumpre deveres que lhe são inerentes em virtude do poder familiar, seja porque negligenciou a criação e educação de sua prole.

Tal conduta omissiva, aliada ao preenchimento dos demais elementos, poderá gerar o dever de indenizar.

\subsection{2 - Dano}

Obviamente a ausência do pai na formação de sua prole é danosa, isto é, gera danos ao filho. Trata-se de danos psíquicos ou também chamados danos à personalidade do indivíduo.

Venosa ensina:

O dano psíquico é modalidade inserida na categoria de danos morais, para efeitos de indenização. O dano psicológico pressupõe modificação de personalidade, com sintomas palpáveis, inibições, depressões, bloqueios etc. ${ }^{126}$

A criança que é privada de ter uma relação afetuosa e atenciosa com seu genitor possui muitas carências, como citou Venosa, podendo sofrer depressões para toda a vida. Muitos estudos que tratam do caso já concluíram que estas crianças abandonadas afetivamente possuem

\footnotetext{
${ }^{125}$ LÔBO, Paulo Luiz Netto. Direito Civil: famílias. $4^{a}$ ed. São Paulo: Saraiva, 2011. p. 71-72.

${ }^{126}$ VENOSA, Sílvio de Salvo. Direito Civil: Responsabilidade civil. $5^{\mathrm{a}}$ ed. São Paulo: Atlas, 2005. p. 49.
} 
consequências danosas na sua estrutura psíquica, como exemplo, baixa auto estima, modificação da personalidade, agressividade, entre outras.

Os pais e seus cuidados são essenciais nos primeiros anos de formação de um ser humano. A criança precisa de carinho, cuidado e educação, isto é, precisa aprender a ter limites e a se relacionar socialmente, e como se sabe os pais serão os responsáveis em cuidar do desenvolvimento pleno desses menores.

Nesse sentido Pereira explica que qualquer criança para ter um desenvolvimento pleno e saudável e para se estruturar como sujeito precisa de alimentos para o corpo e para a alma. E o alimento para a alma seria o amor, que não pode faltar para o desenvolvimento de uma criança. ${ }^{127}$

Sobre a ausência de afeto do pai, Hironaka escreve:

A ausência injustificada do pai origina - em situações corriqueiras - evidente dor psíquica e consequente prejuízo à formação da criança, decorrente da falta não só do afeto, mas do cuidado e da proteção (função psicopedagódica) que a presença paterna representa na vida do filho, mormente quando entre eles já se estabeleceu um vínculo de afetividade. ${ }^{128}$

Desse modo, o ilícito gerador da indenização estaria presente no descumprimento dos deveres inerentes ao exercício do poder familiar, que por sua vez geraria um dano aos direitos da personalidade da criança. ${ }^{129}$

Sendo assim, quando há esse dever de agir por parte do pai e este se omite em prestar a assistência imaterial necessária, gerando um dano moral grave aos seus descendentes, deve o genitor ser responsável em reparar este dano.

\footnotetext{
${ }^{127}$ PEREIRA Rodrigo da Cunha. Nem só de pão vive o Homem: Responsabilidade civil por abandono afetivo. Disponível em: <http://www.ibdfam.org.br/novosite/artigos/detalhe/392>. Acesso em 09 de outubro de 2012.

${ }^{128}$ HIRONAKA Giselda Maria Fernandes Novaes. Pressuposto, elementos e limites do dever de indenizar por abandono afetivo. In: PEREIRA, Tânia da Silva; PEREIRA, Rodrigo Cunha (Coords.). A ética da convivência familiar e sua efetividade no cotidiano dos tribunais. Rio de Janeiro: Forense, 2006. p. 141.

${ }^{129}$ PEREIRA Rodrigo da Cunha. Nem só de pão vive o Homem: Responsabilidade civil por abandono afetivo. Disponível em: <http://www.ibdfam.org.br/novosite/artigos/detalhe/392>. Acesso em 09 de outubro de 2012.
} 


\subsection{3 - Culpa}

Além de ser indispensável a concretização de um dano, como explicitado acima, para que haja o dever de indenizar, também é necessário a comprovação da culpa do pai que se ocultou à convivência com o filho de forma deliberada, se negando a participar do desenvolvimento de sua personalidade, de forma negligente ou imprudente. ${ }^{130}$

Sendo assim, deve-se provar que o individuo não se desenvolveu de forma plena, possuindo graves danos, porque o seu genitor se omitiu de prestar assistência imaterial e sabia que assim estava agindo, isto é, o pai, sabendo da existência de seu descendente, preferiu se omitir em seus deveres, assumindo, sabidamente, as consequências negativas que sua atitude omissiva geraria na formação de sua prole. Provando assim a culpa na sua forma omissiva.

Sabe-se que para verificar a ocorrência de uma conduta culposa compara-se o comportamento do pai à de um homem médio. Assim, o que se espera de um homem médio, que tenha um filho, é o mínimo de assistência material e imaterial necessária para a plena formação da criança.

Desse modo, para que haja o dever de indenizar é preciso que fique provada a culpa na conduta do pai, que agiu de forma contrária ao direito e do que se espera de um homem médio. Não importando se este pai agiu intencionalmente ou não, uma vez que, ao se ausentar dos cuidados que deveria ter em relação a um filho, não agindo como um homem/pai médio, o dano que o filho vai sofrer é previsível.

Vale ainda destacar que este elemento é muito importante para avaliar o cabimento do dever de indenizar, já que se não houver culpa do pai, isto é, se ele for impedido de conviver com o filho por motivos alheios

\footnotetext{
${ }^{130}$ HIRONAKA Giselda Maria Fernandes Novaes. Pressuposto, elementos e limites do dever de indenizar por abandono afetivo. In: PEREIRA, Tânia da Silva; PEREIRA, Rodrigo Cunha (Coords.). A ética da convivência familiar e sua efetividade no cotidiano dos tribunais. Rio de Janeiro: Forense, 2006. p. 143.
} 
à sua vontade, não será caracterizada sua responsabilidade. Hironaka traz alguns exemplos desses fatores:

como será o caso da fixação do domicílio em distância considerável, que encareça os deslocamentos a fim do cumprimento do dever de educar e conviver, mormente em hipóteses de famílias menos abastadas, assim como na hipótese de doença do genitor que, a bem dos filhos, prefere se afastar para não os colocar em situação de risco, além, ainda, da comum hipótese de não se saber se, realmente, este suposto incumprimento é imputável à própria omissão do genitor nãoguardião ou aos obstáculos e impedimentos por parte do genitor guardião. ${ }^{131}$

Diante disso, para que se preencha o elemento culpa e se caracterize o dever de indenizar, é necessário observar se o pai deixou de prestar assistência imaterial ao filho por vontade própria, sendo omisso de forma negligente ou imprudente, já que, neste caso, seria responsável pelos danos causados.

\subsection{4 - Nexo de causalidade}

Este talvez seja o elemento mais difícil de se configurar. Uma vez que, observada a conduta omissiva e culposa do pai e o dano sofrido pelo filho, deve-se analisar se foi realmente esse abandono do pai que gerou tal dano, já que para haver o dever de indenizar deve existir um nexo de causalidade entre o comportamento do pai e o prejuízo do filho.

Sobre o tema, Hironaka ensina que o que produz o liame necessário (nexo de causalidade essencial), para ocorrer a responsabilidade civil por abandono afetivo, é a consequência prejudicial e nefasta na esfera íntima, subjetiva e moral, resultante em dano psíquico ao filho, pelo fato desse abandono culposo do pai. ${ }^{132}$

E para configurar essa relação de causalidade, sendo um elemento de difícil comprovação, será necessário uma perícia, isto é, uma análise

\footnotetext{
${ }^{131}$ Ibid. p. 143.

${ }^{132}$ HIRONAKA Giselda Maria Fernandes Novaes. Os contornos jurídicos da responsabilidade afetiva na relação entre pais e filhos - além da obrigação legal de caráter material. Disponível em: 〈http://www.ibdfam.org.br/novosite/artigos/detalhe/289>. Acesso em 09 de outubro de 2012.
} 
psicológica feita por profissionais especializados e habilitados para tal. Assim, essa perícia deverá demonstrar que o dano sofrido pelo filho foi causado pelo abandono afetivo do pai.

Dessa forma, conseguindo provar a conduta culposa e omissiva do pai na prestação de assistência imaterial ao filho, e que esta omissão deu causa a um dano grave ao filho, se configurará o dever de reparar.

Concluindo nas palavras de Nader:

Os pais que se limitam à assistência material, simplesmente pagando alimentos aos filhos, podem ser acusados de abandono emocional e se sujeitarem à responsabilidade civil pelo descumprimento de seu dever e por causarem danos morais irreversíveis. O judiciário registra casos desta natureza e não há como se negar o direito de ressarcimento, provando-se: o dano moral, o abandono emocional, o nexo de causa e efeito entre ambos e o elemento culpa. ${ }^{133}$

Portanto, analisados os elementos caracterizadores da responsabilidade civil por abandono afetivo, passemos a analisar como a jurisprudência se posiciona sobre o tema. Por se tratar de uma questão existencial, que envolve sentimentos e afeto, o que dificulta a análise real do dano, culpa e nexo causal, alguns entendem ser cabível a reparação outros entendem que não. Vejamos.

\section{3 - Posições jurisprudenciais favoráveis à configuração do dano moral por abandono afetivo}

Um dos primeiros precedentes acerca da responsabilização civil do pai por abandono afetivo é a decisão do Juiz Mário Romano Maggioni, proferida em 16 de setembro de 2003, referente ao processo n. 141/1030012032-0, da $2^{\text {a }}$ Vara Cível da Comarca de Capão da Canoa, Estado do Rio Grande do Sul ${ }^{134}$.

\footnotetext{
${ }^{133}$ NADER, Paulo. Curso de direito civil: Direito de família. Volume 5. $2^{\mathrm{a}}$ ed. Rio de Janeiro: Forense, 2008. p. 335.

${ }^{134}$ COMARCA DE CAPÃO DA CANOA/RS, Processo n. 141/1030012032-0, Juiz Mário Romano Maggioni, Rio Grande do Sul, julgado em 15 de setembro de 2003.
} 
Neste caso, apesar de pagar a pensão alimentícia normalmente, o pai não cumpria o dever de convivência, abandonando afetivamente sua filha desde os 10 anos de idade. Quando a mesma se encontrava com 23 anos ajuizou a ação contra o genitor alegando a rejeição e os sofrimentos que teve. Em primeira instância, o pai foi condenado a pagar uma indenização no valor de 200 (duzentos) salários mínimos e, como o genitor foi revel, a decisão transitou em julgado.

O juiz de direito Maggioni fundamentou sua decisão no fato de que a educação não abrange somente a escolaridade, mas também a convivência familiar, afeto, amor, jogar futebol, ir ao parque, brincar, visitar, criar condições para que a criança se auto-afirme. Desse modo, ele afirma que a ausência e a rejeição do pai violam a honra e a imagem da criança.

O magistrado ainda relembrou que a função paterna abrange amar os filhos, isto é, não basta somente ser pai biológico ou prestar alimentos aos filhos, uma vez que o sustento é apenas uma das parcelas da paternidade.

No ano de 2004, outra decisão importante sobre o tema foi da $7^{\mathrm{a}}$ Câmara Cível do Tribunal de Alçada de Minas Gerais, que reformou a decisão de improcedência proferida em primeira instância na Comarca de Belo Horizonte. A apelação cível n. 408-550-5, julgada em 01 de abril de 2004, foi relatada pelo Juiz Unias da Silva, e condenou o pai a indenizar os sofrimentos causados ao filho pelo abandono afetivo no valor de $\mathrm{R} \$$ 44.000,00 (quarenta e quatro mil reais). É a ementa da decisão:

\footnotetext{
EMENTA - INDENIZAÇÃO DANOS MORAIS - RELAÇÃO PATERNOFILIAL - PRINCÍPIO DA DIGNIDADE DA PESSOA HUMANA PRINCÍPIO DA AFETIVIDADE

A dor sofrida pelo filho, em virtude do abandono paterno, que o privou do direito à convivência, ao amparo afetivo, moral e psíquico, deve ser indenizável, com fulcro no princípio da dignidade da pessoa humana. ${ }^{135}$
}

O Juiz relator da apelação fundamentou seu voto da seguinte maneira:

\footnotetext{
135 TA/MG, Sétima Câmara Cível, Apelação Cível n. 408-550-5, Rel. Juiz Unias Silva, Belo Horizonte, julgado em 01 de abril de 2004.
} 


\begin{abstract}
A relação paterno-filial em conjugação com a responsabilidade possui fundamento naturalmente jurídico, mas essencialmente justo, de se buscar compensação indenizatória em face de danos que pais possam causar a seus filhos, por força de uma conduta imprópria, especialmente quando a eles é negada a convivência, o amparo afetivo, moral e psíquico, bem como a referência paterna ou materna concretas, acarretando a violação de direitos próprios da personalidade humana, magoando seus mais sublimes valores e garantias, como a honra, o nome, a dignidade, a moral, a reputação social, o que, por si só, é profundamente grave. ${ }^{136}$
\end{abstract}

Essa decisão nos mostra que o relator abordou o abandono afetivo como causador de uma violação aos direitos da personalidade do filho, e consequentemente, como violador do princípio da dignidade da pessoa humana.

No entendimento do juiz ficou configurado o dano sofrido pelo filho em relação à sua dignidade, a conduta ilícita do pai que deixou de cumprir seus deveres de convívio e educação, e o nexo causal entre ambos, gerando assim o dever de indenizar.

Vale ressaltar que esta decisão foi posteriormente reformada pelo Superior Tribunal de Justiça, que por sua vez entendeu pelo não cabimento de danos morais. Contudo, trataremos melhor dessa posição mais a frente no tópico acerca do posicionamento do Superior Tribunal sobre o abandono afetivo.

No Tribunal de Justiça do Rio Grande do Sul, encontramos em 2007 decisão também favorável, que assim dispõe:

\begin{abstract}
APELAÇÃO CÍVEL. INDENIZAÇÃO DANOS MATERIAIS E MORAIS. ABANDONO DO FILHO. FALTA DE AMPARO AFETIVO E MATERIAL POR PARTE DO PAI. HONORÁRIOS ADVOCATÍCIOS. REDIMENCIONAMENTO.

A responsabilidade civil, no Direito de Família, é subjetiva. O dever de indenizar decorre do agir doloso ou culposo do agente.

No caso, restando caracterizada a conduta ilícita do pai em relação ao filho, bem como o nexo de causalidade e o dano, cabe indenização por danos materiais e morais.

Nas demandas condenatórias, a verba honorária deve incidir sobre o valor da condenação. Inteligência do art. $20, \S 3^{\circ}$, do CPC.
\end{abstract}

\footnotetext{
${ }^{136}$ TA/MG, Sétima Câmara Cível, Apelação Cível n. 408-550-5, Rel. Juiz Unias Silva, Belo Horizonte, julgado em 01 de abril de 2004.
} 


\section{RECURSO DO AUTOR PARCIALMENTE PROVIDO. APELAÇÃO DO REQUERIDO IMPROVIDO. ${ }^{137}$}

Já no ano de 2008, o Tribunal de Justiça de Santa Catarina julgou caso semelhante, e o Relator Desembargador Monteiro Rocha assim entendeu em seu voto:

Haja vista a imprescindibilidade da presença paterna na existência do indivíduo e, tendo em conta os efeitos negativos da ausência do pai na vida do filho, é inegável que o abandono afetivo constitui ato atentatório à dignidade da pessoa humana em processo de desenvolvimento e hábil a gerar dano moral. ${ }^{138}$

E ainda prossegue o relator: "considerando a premissa de que aquele que causa o dano fica obrigado a repará-lo, daí surge ao pai a obrigação de indenizar os abalos suportados pelo filho abandonado."

Recentemente, em maio de 2012, a $12^{\text {a }}$ Câmara Cível do Tribunal de Justiça do Estado do Rio de Janeiro, no julgamento da apelação cível n. 0154617-61.2010.8.19.0001, também firmou entendimento no sentido de que o abandono afetivo por parte do genitor caracteriza dano moral passível de indenização. Assim dispõe a ementa:

APELAÇÃO CÍVEL. ABANDONO AFETIVO. GENITOR. DANOS MORAIS. DEVER DE INDENIZAR. Inobstante as controvérsias existentes sobre o tema, inclusive no âmbito do STJ, o abandono afetivo por parte do genitor, capaz de gerar dor, vergonha e sofrimento, caracteriza dano moral passível de indenização. O valor arbitrado a título de indenização, deve atender aos parâmetros do razoável e proporcional. Recursos aos quais se nega provimento. ${ }^{139}$

Esses são alguns exemplos de decisões proferidas ao longo dos recentes anos acolhendo os pedidos de indenização em danos morais por abandono afetivo do genitor. Como pode-se notar a maioria dos magistrados demonstra preocupação com a integridade psíquica da criança, que sofre dor e abalos emocionais ao ser rejeitada por seu genitor.

\footnotetext{
137 TJ/RS, Oitava Câmara Cível, Apelação Cível n. 70021427695, Rel. Des. Claudir Fidelis Faccenda, Rio Grande do Sul, julgado em 29 de novembro de 2007.

${ }_{138}$ TJ/SC, Segunda Câmara de Direito Civil, Apelação Cível n. 2006.015053-0, Rel. Des. Monteiro Rocha, Santa Catarina, julgado em 10 de dezembro de 2008.

${ }^{139}$ TJ/RJ, Décima Segunda Câmara Cível, Apelação Cível n. 0154617-61.2010.8.19.0001, Rel. Des. Cherubin Schwartz, Rio de Janeiro, julgado em 3 de maio de 2012.
} 
O princípio da dignidade da pessoa humana é o corolário de maior importância nestas decisões favoráveis, já que a criança e o adolescente devem ser vistos sempre como um ser em formação, que ainda não possuem o completo desenvolvimento e por isso necessitam do amor, do afeto e do cuidado de ambos os pais para transformarem-se em adultos saudáveis, sem complexos e frustrações.

Portanto, o que estas decisões tentam mostrar é que o amor e o afeto são direitos natos dos filhos, que não podem ser punidos por ressentimentos e brigas de seus pais, já que a falta de afeto entre pais e filhos reflete negativamente na formação e no desenvolvimento do menor, permitindo a criação de carências incuráveis e de resultados devastadores na autoestima do indivíduo. ${ }^{140}$

\section{4 - Posições jurisprudenciais desfavoráveis à configuração do dano moral por abandono afetivo}

Em contraposição às decisões demonstradas acima, passaremos a analisar os julgamentos que não acolhem os pedidos de indenização por abandono afetivo e os motivos usados para tanto.

No ano de 2008, a $4^{\mathrm{a}}$ Câmara de Direito Privado do Tribunal de Justiça de São Paulo, no julgamento da Apelação Cível n. 599506490, entendeu que o abandono afetivo do genitor não caracteriza-se como ato ilícito gerador de indenização, isto é, a Câmara entendeu que ao relacionamento desprovido de vínculo afetivo entre pai e filho não se atribui dolo ou culpa aptos a ensejar reparação civil. Assim dispôs o Relator Desembargador Maia da Cunha:

A ofensa à integridade psíquica determinada pelo réu, com ou sem a concorrência da mãe do autor, não configura ilicitude geradora de danos morais. Até se reconhece a possibilidade de dor psicológica do requerente, mas em sua origem não se aloca culpa ou dolo apto a representar ato ilícito e, assim, estanca o

\footnotetext{
${ }^{140}$ MADALENO, Rolf. Curso de Direito de Família. $4^{\mathrm{a}}$ ed. Rio de Janeiro: Forense, 2011. p. 379.
} 
desdobramento para a responsabilidade civil extracontratual, afastando a obrigação de ressarcimento. ${ }^{141}$

Da mesma maneira decidiu a $8^{\text {a }}$ Câmara Cível do Tribunal de Justiça do Rio Grande do Sul ao julgar o caso de duas crianças que entraram com pedido de indenização em danos morais por abandono afetivo do pai. $\mathrm{O}$ Relator Desembargador Luiz Felipe Brasil Santos não detectou no abandono do pai conduta que tenha causado dano aos menores, não configurando assim ato ilícito gerador de responsabilização.

Assim concluiu a ementa:

No direito de família, o dano moral é, em tese, cabível. No entanto, imprescindível que haja a configuração do ato ilícito. O distanciamento do varão em relação aos filhos não constitui motivo para fundamentar a indenização por dano moral, sendo tal fato um acontecimento bastante recorrente, um fato da vida, apesar de lamentável. Embora seja plausível que os apelantes tenham sofrido pela ausência do pai, essa situação não pode ser atribuída ao genitor somente, a ponto de levar à obrigação de indenizar. Ademais, em que pese reprovável, a conduta do demandado não se enquadra no conceito jurídico de ato ilícito, que gera o dever de indenizar. ${ }^{142}$

Como se depreende desses 2 julgados alguns juízes e Câmaras Cíveis por todo o país rejeitam o pedido de danos morais por abandono paterno entendendo, nos casos concretos, que não há configuração de um ato ilícito capaz de gerar tal indenização. Entretanto, a maioria dos julgados que rejeitam este pedido tem suas decisões fundamentadas no fato de que ninguém é obrigado a amar o outro.

Em 2008, no julgamento da apelação cível n. 2007.001.63727, em que o filho postulava danos morais em face do pai ao argumento de falta de amor, a $11^{\text {a }}$ Câmara Cível do Tribunal de Justiça do Rio de Janeiro, por unanimidade, entendeu que "ninguém é obrigado a amar ou continuar amando outrem"143.

\footnotetext{
${ }^{141}$ TJ/SP, Quarta Câmara de Direito Privado, Apelação Cível n. 599506490, Rel. Des. Maia da Cunha, São Paulo, julgado em 11 de dezembro de 2008.

${ }^{142}$ TJ/RS, Oitava Câmara Cível, Apelação Cível n. 70044172401, Rel. Des. Luiz Felipe Brasil Santos, rio Grande do Sul, julgado em 13 de outubro de 2011.

${ }_{143}$ TJ/RJ, Décima Primeira Câmara Cível, Apelação Cível n. 2007.001.63727, Rel. Des. José Carlos de Figueiredo, Rio de Janeiro, julgado em 9 de abril de 2008.
} 
Em seu voto, o relator Desembargador José Carlos Figueiredo, explicou que:

\begin{abstract}
Não pode o Poder Judiciário determinar a alguém que passe ou volte a amar outrem e, em caso contrário, determinar reparação pecuniária. Na verdade, as queixas e a pretensão de se ver compensado pecuniariamente pela eventual falta de amor paterno repita-se, se traduz numa espécie de castigo que o filho quer impor ao pai, com o que não se pode concordar. ${ }^{144}$
\end{abstract}

Em outra apelação, de n. 70019263409 do Tribunal de Justiça do Rio Grande do Sul, o filho, gerado de uma relação casual entre os genitores e reconhecido em ação de investigação de paternidade, pleiteou a indenização por abandono afetivo. Sobre a descoberta da paternidade por força de ação judicial, assim entendeu o relator quanto ao abandono:

E não se pode exigir, como num passe de mágica, que, por força da sentença que o declarou pai - melhor dito, que o declarou genitor, porque o conceito de pai pressupõe um dado socioafetivo constituído na convivência, e não é uma mera decorrência do vínculo genético -, que o apelado tome-se de amores pelo filho e o introduza na família que constituiu, mormente quando se percebe que o nãoreconhecimento espontâneo da paternidade deixou mágoas nos envolvidos, o que é de certo modo natural em situações dessa natureza. ${ }^{145}$

Ainda neste julgamento a Desembargadora Maria Berenice Dias, indo em sentido oposto aos outros desembargadores, assim dispôs em seu voto:

Está mais do que comprovado, que a carência do convívio com um dos genitores traz sequelas significativas para o desenvolvimento normal de uma criança. $\mathrm{O}$ autor não está buscando o afeto do pai, não lhe está cobrando a falta de atenção. Está buscando reparação pelo abandono em face da carência afetiva, o que lhe gera danos, consequências para o seu pleno desenvolvimento. ${ }^{146}$

\footnotetext{
${ }^{144}$ TJ/RJ, Décima Primeira Câmara Cível, Apelação Cível n. 2007.001.63727, Rel. Des. José Carlos de Figueiredo, Rio de Janeiro, julgado em 9 de abril de 2008.

${ }^{145}$ TJ/RS, Sétima Câmara Cível, Apelação Cível n. 70019263409, Rel. Des. Luiz Felipe Brasil Santos, Rio Grande do Sul, julgado em 8 de agosto de 2007.

${ }_{146}$ TJ/RS, Sétima Câmara Cível, Apelação Cível n. 70019263409, Rel. Des. Luiz Felipe Brasil Santos, Rio Grande do Sul, julgado em 8 de agosto de 2007.
} 
Contudo, seu voto foi vencido e a apelação do filho abandonado afetivamente foi desprovida, concluindo-se assim pelo não acolhimento do pedido de indenização por falta de amor do pai.

Recentemente, em março de 2012, o Tribunal do Rio Grande do Sul proferiu outra decisão no mesmo sentido desta acima, ao julgar a apelação cível n. 70045481207. Neste caso, bastante parecido com os demais, a filha alega abandono afetivo do pai, ao privá-la da convivência com o mesmo, e que lhe gerou dor, devendo ser indenizada com base no princípio da dignidade da pessoa humana.

A relatora do caso, Desembargadora Liselena Schifino Robles Ribeiro, entendeu que o distanciamento afetivo entre pai e filha decorreu de fatos da vida, não sendo capaz de gerar dano moral e nem implicando em ofensa ao princípio da dignidade da pessoa humana, este já vulgarizado na visão da relatora. ${ }^{147}$

A desembargadora ainda concluiu que a conduta do pai não violou qualquer direito da autora. Assim discorreu: "a falta de carinho, de "afeto", de amizade ou de atenções que denotem o amor paternal, é fato lamentável, mas não constitui, em si, a violação de direito algum." ${ }^{148}$

A ementa desta decisão traz o seguinte trecho:

Embora se viva num mundo materialista, nem tudo pode ser resolvido pela solução simplista da indenização, pois afeto não tem preço, e valor econômico nenhum poderá restituir o valor de um abraço, de um beijo, enfim de um vínculo amoroso saudável entre pai e filho, sendo essa perda experimentada tanto por um quanto pelo outro. ${ }^{149}$

Portanto, vimos alguns exemplos de posições jurisprudenciais desfavoráveis, e existem diferentes motivos para esse não acolhimento, os quais analisaremos melhor no tópico da conclusão. Contudo, seja pelo fundamento de que ninguém é obrigado a amar o outro, de que não houve

\footnotetext{
${ }^{147}$ TJ/RS, Sétima Câmara Cível, Apelação Cível n. 70045481207, Relatora Des. ${ }^{a}$ Liselena Schifino Robles Ribeiro, Rio Grande do Sul, julgado em 28 de março de 2012.

${ }_{148}$ TJ/RS, Sétima Câmara Cível, Apelação Cível n. 70045481207, Relatora Des. ${ }^{a}$ Liselena Schifino Robles Ribeiro, Rio Grande do Sul, julgado em 28 de março de 2012.

${ }_{149}$ TJ/RS, Sétima Câmara Cível, Apelação Cível n. 70045481207, Relatora Des. ${ }^{a}$ Liselena Schifino Robles Ribeiro, Rio Grande do Sul, julgado em 28 de março de 2012.
} 
ato ilícito ou não houve comprovação de dano, de que não se pode vulgarizar o princípio da dignidade da pessoa humana e banalizar os vínculos familiares, ou pelo fato de que o afeto não tem preço. Seja qual for o motivo, o que vinha predominando na jurisprudência dos tribunais brasileiros até os dias atuais era a rejeição desses pleitos, tendo inclusive precedentes do Superior Tribunal de Justiça nesse sentido.

Contudo, com a constante evolução do direito de família, as ideias começam a mudar e começamos a ver uma transformação jurisprudencial em sentido oposto, como é o caso da recente posição da Terceira Turma do Superior Tribunal de Justiça sobre o tema. É o que passaremos a analisar.

\section{5 - Posicionamento do Superior Tribunal de Justiça: mudança de entendimento}

Como já citado, um dos primeiros casos de abandono afetivo paterno foi aquele julgado pelo Tribunal de Alçada de Minas Gerais, no qual o Tribunal reformou a decisão de primeira instância e condenou o genitor a pagar um valor de $\mathrm{R} \$ 44.000,00$ (quarenta e quatro mil reais) ao filho, entendendo que a conduta ilícita do genitor, ao não cumprir seu dever de convívio com o filho, gerou um dano à dignidade do menor.

Este foi o primeiro episódio sobre o tema a chegar ao Superior Tribunal de Justiça, uma vez que o genitor interpôs o Recurso Especial n. 757-411 contra a decisão do Tribunal de Minas Gerais, alegando que não existia dolo ou culpa no caso, e nem os elementos caracterizadores do ato ilícito para gerar uma indenização.

Neste julgamento, a Quarta Turma do STJ não manteve a decisão de segunda instância, dando provimento ao recurso especial por maioria e levando à improcedência do pleito autoral. Assim concluiu a ementa:

EMENTA. RESPONSABILIDADE CIVIL. ABANDONO MORAL. REPARAÇÃO. DANOS MORAIS. IMPOSSIBILIDADE. 1. A indenização por 
dano moral pressupõe a prática de ato ilícito, não rendendo ensejo à aplicabilidade da norma do art. 159 do Código Civil de 1916 o abandono afetivo, incapaz de reparação pecuniária. 2. Recurso especial conhecido e provido. ${ }^{150}$

O relator do recurso, Ministro Fernando Gonçalves, acompanhado pelos Ministros Aldir Passarinho Júnior, Jorge Scartezzini e César Asfor Rocha, decidiu por conhecer e dar provimento ao recurso, entendendo que o abandono afetivo do genitor não caracteriza um dano indenizável, que o direito de família já traz a perda do poder familiar como uma punição para o abandono e que não se pode obrigar um pai a amar o filho.

Assim discorreu o relator:

No caso de abandono ou do descumprimento injustificado do dever de sustento, guarda e educação dos filhos, porém, a legislação prevê como punição a perda do poder familiar. [...] Assim, o ordenamento jurídico, com a determinação da perda do poder familiar, a mais grave pena civil a ser imputada a um pai, já se encarrega da função punitiva e, principalmente, dissuasória, mostrando eficientemente aos indivíduos que o direito e a sociedade não se compadecem com a conduta do abandono, com o que cai por terra a justificativa mais pungente dos que defendem a indenização pelo abandono moral. ${ }^{151}$

\section{E concluiu:}

Como escapa ao arbítrio do Judiciário obrigar alguém a amar, ou a manter um relacionamento afetivo, nenhuma finalidade positiva seria alcançada com a indenização pleiteada. [...] Inexistindo a possibilidade de reparação a que alude o art. 159 do Código Civil de 1916, não há como reconhecer o abandono afetivo como dano passível de indenização. ${ }^{152}$

Vale ressaltar que neste julgamento houve apenas um voto vencido, do Ministro Barros Monteiro, que asseverou não existir nenhuma excludente de responsabilidade do pai, já que sequer foi cogitada alguma excludente, e então, ele entendeu que estavam presentes a conduta ilícita, o dano e o nexo de causalidade. Por fim, ainda assegurou que a destituição do

\footnotetext{
${ }^{150}$ STJ, Recurso Especial n. 757-411/MG, Rel. Min. Fernando Gonçalves, Quarta Turma, Brasília, julgado em 29 de novembro de 2005.

${ }^{151}$ STJ, Recurso Especial n. 757-411/MG, Rel. Min. Fernando Gonçalves, Quarta Turma, Brasília, julgado em 29 de novembro de 2005.

${ }^{152}$ STJ, Recurso Especial n. 757-411/MG, Rel. Min. Fernando Gonçalves, Quarta Turma, Brasília, julgado em 29 de novembro de 2005.
} 
poder familiar não interfere na indenização por dano moral, isto é, a indenização é devida além dessa outra sanção.

Em outro caso, Recurso Especial n. 514.350/SP ${ }^{153}$, julgado no ano de 2009 pelo STJ, a Quarta Turma, utilizando o precedente de 2005, reafirmou seu posicionamento no sentido de não ser o abandono afetivo dano passível de reparação.

Vale transcrever o informativo do STJ de número 0392, do período de 27 de abril a $1^{\circ}$ de maio de 2009, que traz a posição adotada pelo STJ neste recurso especial, e usa como precedente o primeiro caso acima citado:

Informativo n. 0392. Período: 27 de abril a $1^{\circ}$ de maio de 2009. Quarta Turma. ABANDONO MORAL. REPARAÇÃO. DANOS MORAIS. IMPOSSIBILIDADE. Trata-se de ação de investigação de paternidade em que o ora recorrente teve o reconhecimento da filiação, mas o Tribunal a quo excluiu os danos morais resultantes do abandono moral e afetivo obtidos no primeiro grau. A Turma entendeu que não pode o Judiciário compelir alguém a um relacionamento afetivo e nenhuma finalidade positiva seria alcançada com a indenização pleiteada. Assim, por não haver nenhuma possibilidade de reparação a que alude o art. 159 do CC/1916 (pressupõe prática de ato ilícito), não há como reconhecer o abandono afetivo como dano passível de reparação. Logo a Turma não conheceu do recurso especial. Precedente citado: REsp 757.411-MG, DJ 27/3/2006. REsp 514.350-SP, Rel. Min. Aldir Passarinho Junior, julgado em $28 / 4 / 2009 .{ }^{154}$

Com isso, percebemos que o entendimento do STJ até então era contrário ao cabimento de indenização em danos morais por abandono afetivo. Entretanto, em julgamento recente, isto é, em 24 de abril de 2012, a Terceira Turma do Superior Tribunal de Justiça, em sentido oposto, deixou claro ser possível uma condenação dos pais que abandonam afetivamente seus filhos.

153 “CIVIL E PROCESSUAL. AÇÃO DE INVESTIGAÇÃO DE PATERNIDADE. RECONHECIMENTO. DANOS MORAIS REJEITADOS. ATO ILÍCITO NÃO CONFIGURADO. I. Firmou o Superior Tribunal de Justiça que "A indenização por dano moral pressupõe a prática de ato ilícito, não rendendo ensejo à aplicabilidade da norma do art. 159 do código Civil de 1916 o abandono afetivo, incapaz de reparação pecuniária" (Resp. n. 757.411/MG, $4^{a}$ Turma, Rel. Min. Fernando Gonçalves, unânime, DJU de 29.11.2005). II. Recurso especial não conhecido". BRASIL, Superior Tribunal de Justiça. Recurso Especial n. 514.350/SP. Relator Min. Aldir Passarinho Junior, Quarta Turma, julgado em 28 de abril de 2009.

${ }^{154}$ STJ, Informativo n. 0392, Período: 27 de abril a $1^{\circ}$ de maio de 2009, Quarta Turma. Disponível em:

$<$ http://www.stj.jus.br/SCON/infojur/toc.jsp?livre=0392\&\&b=INFJ\&p=true \&t=JURIDICO\&l=10 $\& \mathrm{i}=21>$. Acesso em 16 de outubro de 2012. 
O caso iniciou-se na Comarca de Sorocaba, com uma ação de indenização proposta pela filha contra o pai, após ter a paternidade reconhecida judicialmente, alegando que sofreu abandono afetivo e material durante toda a infância e adolescência.

Em primeira instância, o juiz julgou improcedente a ação por entender que o distanciamento entre as partes se deu em virtude do comportamento agressivo da genitora em relação ao pai, e por isso, não deveria haver o direito de reparar.

A autora recorreu da decisão e, em segunda instância, o Tribunal de Justiça de São Paulo deu provimento a apelação e fixou uma compensação por danos morais no valor de $\mathrm{R} \$ 415.000,00$ (quatrocentos e quinze mil reais), entendendo que o genitor era abastado e prospero ${ }^{155}$.

Já em sede de recurso especial, o pai alegou violação a diversos dispositivos do Código Civil e dissídio jurisprudencial, dizendo que a decisão do Tribunal de São Paulo diverge do posicionamento do STJ consubstanciado no julgamento do já citado Recurso Especial n. 757.411MG.

Ainda, o genitor sustentou que não abandonou a filha e, mesmo que o tivesse feito, tal fato não configuraria um ato ilícito indenizável, sendo a perda do poder familiar a única sanção cabível para punir o abandono. E em pedido sucessivo, pediu a diminuição do valor fixado a título de compensação por danos morais.

Diante desse Recurso Especial n. 1.159.242-SP ${ }^{156}$, a Terceira Turma do STJ, por maioria, deu parcial provimento ao recurso, mantendo a condenação do pai para indenizar a filha pelo abandono afetivo, mas

155 “AČ̃̃ DE INDENIZAÇ̃̃O. DANOS MORAIS E MATERIAIS. FILHA HAVIDA DE RELAÇÃO AMOROSA ANTERIOR. ABANDONO MORAL E MATERIAL. PATERNIDADE RECONHECIDA JUDICIALMENTE. PAGAMENTO DA PENSÃO ARBITRADA EM DOIS SALÁRIOS MÍNIMOS ATÉ A MAIORIDADE. ALIMENTANTE ABASTADO E PRÓSPERO. IMPROCEDÊNCIA. APELAÇÃO. RECURSO PARCIALMENTE PROVIDO.” SÃO PAULO, Tribunal de Justiça. Apelação Cível n. 361.389.4/2-00. Relatora Des. ${ }^{a}$ Daise Fajardo Jacot. $7^{\mathrm{a}}$ Câmara "B" de Direito Privado, julgado em 26 de novembro de 2008.

${ }^{156}$ STJ, Recurso Especial n. 1159242/SP (2009/0193701-9), Rel. Min. Nancy Andrighi, Terceira Turma, Brasília, julgado em 24 de abril de 2012. 
reduzindo o valor dos danos morais para $\mathrm{R} \$ 200.000,00$ (duzentos mil reais).

A frase "amar é faculdade, cuidar é dever", usada pela Relatora Ministra Nancy Andrighi em seu voto, ficou famosa depois desse julgamento e vem demonstrar uma inovação na jurisprudência do Superior Tribunal de Justiça sobre o assunto e a possibilidade de indenização por abandono afetivo do pai.

Passemos então a analisar o julgamento da Terceira Turma, começando por citar a ementa da decisão:

CIVIL E PROCESSUAL CIVIL. FAMÍLIA. ABANDONO AFETIVO. COMPENSAÇÃO POR DANO MORAL. POSSIBILIDADE.

1. Inexistem restrições legais à aplicação das regras concernentes à responsabilidade civil e o consequente dever de indenizar/compensar no Direito de Família.

2. O cuidado como valor jurídico objetivo está incorporado no ordenamento jurídico brasileiro não com essa expressão, mas com locuções e termos que manifestam suas diversas desinências, como se observa do art. 227 da CF/88.

3. Comprovar que a imposição legal de cuidar da prole foi descumprida implica em se reconhecer a ocorrência de ilicitude civil, sob a forma de omissão. Isso porque o non facere, que atinge um bem juridicamente tutelado, leia-se, o necessário dever de criação, educação e companhia - de cuidado - importa em vulneração da imposição legal, exsurgindo, daí, a possibilidade de se pleitear compensação por danos morais por abandono psicológico.

4. Apesar das inúmeras hipóteses que minimizam a possibilidade de pleno cuidado de um dos genitores em relação à sua prole, existe um núcleo mínimo de cuidados parentais que, para além do mero cumprimento da lei, garantam aos filhos, ao menos quanto à afetividade, condições para uma adequada formação psicológica e inserção social.

5. A caracterização do abandono afetivo, a existência de excludentes ou, ainda, fatores atenuantes - por demandarem revolvimento de matéria fática - não podem ser objeto de reavaliação na estreita via do recurso especial.

6. A alteração do valor fixado a título de compensação por danos morais é possível, em recurso especial, nas hipóteses em que a quantia estipulada pelo Tribunal de origem revela-se irrisória ou exagerada.

7. Recurso especial parcialmente provido. ${ }^{157}$

A Ministra Nancy Andrighi começou a explicitação de seu voto sustentando que é cabível sim a indenização em danos morais nas relações familiares, diferentemente do que se sustentava no passado, já que "não existem restrições legais à aplicação das regras relativas à reponsabilidade

\footnotetext{
${ }^{157}$ STJ, Recurso Especial n. 1159242/SP (2009/0193701-9), Rel. Min. Nancy Andrighi, Terceira Turma, Brasília, julgado em 24 de abril de 2012.
} 
civil e o consequente dever de indenizar/compensar, no Direito de Família"158.

Ainda, sobre o argumento de ser a perda do poder familiar a única punição pelo abandono afetivo, a Relatora sustentou que tal punição não afasta a possibilidade de compensações ou indenizações, ou seja, a perda do poder familiar visa garantir a integridade da criança, já que lhe oferta, por outros meios, a educação e criação negada pelo pai, mas nunca vai compensar os danos sofridos pelo malcuidado pai.

A Ministra explica que é difícil identificar os elementos (dano, culpa e nexo causal) que configuram o dano moral quando se trata de relações familiares, porque estas envolvem certo grau de subjetividade, como amor, afeto, mágoa. Contudo, ela aponta que, além desses elementos intangíveis, existem relações, como é o caso da relação entre pais e filhos, que trazem um liame objetivo, calcado no vínculo biológico ou autoimposto (adoção), e para os quais há uma previsão constitucional e legal de obrigações mínimas. Assim discorre:

Sendo esse elo fruto, sempre, de ato volitivo, emerge, para aqueles que concorrem com o nascimento ou adoção, a responsabilidade decorrente de suas ações e escolhas, vale dizer, a criação da prole. [...] Sob esse aspecto, indiscutível o vínculo não apenas afetivo, mas também legal que une pais e filhos, sendo monótono o entendimento doutrinário de que, entre os deveres inerentes ao poder familiar, destacam-se o dever de convívio, de cuidado, de criação e educação dos filhos, vetores que, por óbvio, envolvem a necessária transmissão de atenção e o acompanhamento do desenvolvimento sócio-psicológico da criança. ${ }^{159}$

Sobre a crescente percepção do cuidado como valor jurídico, conforme já foi demonstrado em tópico específico, a Relatora entende que o cuidado é um dever legal e, por isso, tem repercussão na responsabilidade civil, uma vez que é fator crucial na formação da personalidade da criança. Sendo assim, os pais assumiriam obrigações jurídicas em relação aos seus descendentes que vão além das chamadas necessarium vitae.

\footnotetext{
${ }^{158}$ STJ, Recurso Especial n. 1159242/SP (2009/0193701-9), Rel. Min. Nancy Andrighi, Terceira Turma, Brasília, julgado em 24 de abril de 2012.

${ }^{159}$ STJ, Recurso Especial n. 1159242/SP (2009/0193701-9), Rel. Min. Nancy Andrighi, Terceira Turma, Brasília, julgado em 24 de abril de 2012.
} 
Desse modo, quando o cuidado alcança relevância jurídica e é considerado como uma obrigação legal, cai por terra o grande fundamento daqueles que rejeitam a indenização por abandono afetivo ao sustentarem ser impossível obrigar alguém a amar o outro. Assim a Ministra diferencia o amor do cuidado:

Aqui não se fala ou se discute o amor e, sim, a imposição biológica e legal de cuidar, que é dever jurídico, corolário da liberdade das pessoas de gerarem ou adotarem filhos. O amor diz respeito à motivação, questão que refoge os lindes legais. [...] O cuidado, distintamente, é tisnado por elementos objetivos, distinguindo-se do amor pela possibilidade de verificação e comprovação de seu cumprimento. ${ }^{160}$

E explica que a verificação do cumprimento ou não deste dever legal será feita com avaliação das ações concretas, como presença, contato, ações voluntárias em favor da prole, comparação do tratamento dado aos outros filhos quando existirem, entre outras avaliações que o julgador puder apreciar. Assim complementa: "Em suma, amar é faculdade, cuidar é dever".

Desse modo, o descumprimento dessa obrigação legal de cuidado por parte do pai vai configurar um ato ilícito, sob a forma de omissão. Entretanto, a Ministra também ressalvou que deve ser demonstrado o dolo ou culpa do pai, porque não bastaria apenas o distanciamento entre pais e filhos, uma vez que existem algumas excludentes de ilicitude, como por exemplo, a alienação parental, distâncias geográficas, limitações financeiras, etc.

Todas as questões a serem analisadas vão variar caso a caso, mas a Relatora lembra que o julgador não pode se olvidar de que deve existir um núcleo mínimo de cuidados parentais, para garantir ao filho, pelo menos quanto à afetividade, condições para uma apropriada formação psicológica e inserção social.

\footnotetext{
${ }^{160}$ STJ, Recurso Especial n. 1159242/SP (2009/0193701-9), Rel. Min. Nancy Andrighi, Terceira Turma, Brasília, julgado em 24 de abril de 2012.
} 
Quanto à caracterização do dano e do nexo causal, a relatora explica que devem ser observados por um laudo formulado por especialista, que aponte a existência de uma patologia psicológica e a vinculação com o descuido de um dos pais.

No caso analisado, já que não é cabível ao STJ reapreciar os fatos por recurso especial, a Ministra utilizou os fatos estabelecidos pelo Tribunal de origem, e este consolidou que houve negligência do pai nos cuidados com a filha, pela ausência quase completa de contato, e discriminação de tratamento com relação aos outros filhos.

A Relatora asseverou que a filha superou essas dificuldades, a ponto de conseguir inserção profissional, construir uma família com filhos e conduzir sua vida. Todavia, ainda afirmou que não é possível negar que houve sofrimento, tristeza e mágoa, e que estes sofrimentos, por ser considerada como filha de segunda classe, discriminada dos irmãos, ainda persistem.

Concluindo acerca do dano e do nexo causal existentes, a Ministra discorre:

Esse sentimento íntimo que a recorrida levará, ad perpetuam, é perfeitamente apreensível e exsurge, inexoravelmente, das omissões do recorrente no exercício de seu dever de cuidado em relação à recorrida e também de suas ações, que privilegiaram parte de sua prole em detrimento dela, caracterizando o dano in $r$ ipsa e traduzindo-se, assim, em causa eficiente à compensação. ${ }^{161}$

No final de seu voto, porém, a Ministra apenas discordou do valor fixado pelo Tribunal de origem, de $\mathrm{R} \$ 415.000,00$ (quatrocentos e quinze mil reais), entendendo ser demasiadamente elevado, não obstante o grau de violação do dever de cuidado, e desse modo, reduziu o valor para $\mathrm{R} \$$ 200.000,00 (duzentos mil reais).

No julgamento em questão, o único voto vencido foi do Ministro Massami Uyeda, que divergiu da Ministra relatora e votou por dar provimento ao recurso especial, afastando a condenação.

\footnotetext{
${ }^{161}$ STJ, Recurso Especial n. 1159242/SP (2009/0193701-9), Rel. Min. Nancy Andrighi, Terceira Turma, Brasília, julgado em 24 de abril de 2012.
} 
O Ministro entendeu pela impossibilidade de se configurar dano moral por abandono afetivo, já que mensurar manifestações de amor e carinho é muito complexo, e qualquer dado subjetivo ensejaria um pedido de indenização por danos morais. Assim discorreu o Ministro:

\begin{abstract}
Sabemos que a formação das pessoas, e V. Exa. cita, aqui, estudos de psicologia muito bem calcados, os estudos são, eminentemente, programáticos no sentido de que o ideal da convivência das pessoas é que todos tivéssemos uma vida em família harmoniosa, com o pai e a mãe expedindo esse amor, esse carinho, mas manifestação de amor e carinho é meio complexo. Não posso exigir que os meus padrões psicológicos se coloquem na normalidade. ${ }^{162}$
\end{abstract}

E depois o Ministro assevera que, caso seja negado provimento ao recurso especial, se estaria abrindo um precedente muito perigoso, isto é, o STJ poderá passar a cuidar de mágoas familiares:

Abrir essa porta aqui, reconhecer isso como um direito não podemos, com todo o respeito. Existe uma lesão à estima. Todos nós... A nossa vida é feita de perdas e ganhos, talvez até mais de perdas do que de ganhos. [...] Estou dizendo a tese. Se abrirmos essa tese aqui, olha, como diria o pessoal, sai de baixo. Esse Tribunal irá cuidar de mágoas.”163

Mesmo com esta divergência aberta, os demais Ministros, Sidnei Beneti, Paulo de Tarso Sanseverino e Ricardo Villas Bôas Cueva, votaram com a Ministra relatora para dar parcial provimento ao recurso especial, mantendo a condenação do recorrente, mas reduzindo o valor antes fixado.

E, desse modo, o julgamento da Terceira Turma do STJ terminou com a decisão da maioria, condenando o recorrente no valor de R\$ 200.000,00 (duzentos mil reais) a título de compensação por danos morais em favor da filha abandonada afetivamente.

Trata-se de uma novidade na jurisprudência do STJ, mas o caso ainda não está terminado. $\mathrm{O}$ genitor apresentou embargos de divergência, tendo em vista que a decisão contraria o entendimento anterior de outra Turma do STJ sobre o mesmo tema, como já foi exposto no presente

\footnotetext{
${ }^{162}$ STJ, Recurso Especial n. 1159242/SP (2009/0193701-9), Rel. Min. Nancy Andrighi, Terceira Turma, Brasília, julgado em 24 de abril de 2012.

${ }^{163}$ STJ, Recurso Especial n. 1159242/SP (2009/0193701-9), Rel. Min. Nancy Andrighi, Terceira Turma, Brasília, julgado em 24 de abril de 2012.
} 
trabalho. Quem relatará o caso é o Ministro Marco Buzzi, e caberá a ele avaliar se a decisão recorrida realmente conflita com o entendimento anterior de 2005 e se preenche outros requisitos legais. Caso seja admitido, o processo vai ser julgado pelos dez ministros da Segunda Seção do STJ. ${ }^{164}$

Como já dito, esta foi apenas a primeira decisão favorável de uma Turma do Superior Tribunal de Justiça sobre a possibilidade de indenização por abandono afetivo, demonstrando o surgimento de um novo paradigma jurisprudencial, mas lembrando que tal decisão ainda poderá sofrer mudanças.

Deixando de lado o resultado que esse processo poderá ter, o que se torna importante ressaltar é a evolução do pensamento desses ilustres Ministros, refletindo as modificações que vêm ocorrendo nos tribunais de todo o país. Isto é, o dever de cuidado dos pais em relação à sua prole já vem sendo majoritariamente aceito pela doutrina e pela jurisprudência.

${ }^{164}$ STJ. Pai recorre de decisão sobre dano moral por abandono afetivo. Notícia retirada do site do STJ. Disponível 


\section{CAPÍTULO 5 - PROJETOS DE LEI}

Frisando essa nova posição que está surgindo acerca do abandono afetivo, dois projetos de lei tramitam no Congresso Nacional sobre o assunto, um na Câmara dos Deputados e outro no Senado Federal.

Uma das propostas é o Projeto de Lei do Senado n. 700 de 2007, de autoria do Senador Marcelo Crivella (PRB-RJ), que modifica o Estatuto da Criança e do Adolescente (Lei 8.069/90) para caracterizar o abandono moral como ilícito civil e penal.

A proposta traz o dever dos pais de prestar assistência moral aos filhos menores de dezoito anos, seja através do convívio ou através da visitação periódica. Para tanto, compreende-se como assistência moral a orientação sobre as principais escolhas e oportunidades profissionais, educacionais e culturais; a solidariedade e apoio nos momentos de intenso sofrimento ou dificuldade; a presença física solicitada de forma espontânea pela criança e possível de ser atendida.

Ainda, além de impor aos pais o dever de sustento, educação e guarda dos filhos, o projeto de lei visa impor também os deveres de convivência e assistência material e moral.

Outra novidade que o proposta traz é a possibilidade de pena de detenção, de seis meses a um ano, caso o genitor deixe, sem justa causa, de prestar assistência moral ao filho menor de dezoito anos.

Na justificativa do projeto de lei, o Senador deixa claro que amor e afeto não podem ser obrigados por lei, isto é, a ideia da proposta não é obrigar um pai a amar seu filho, mas sim obrigá-lo a se fazer presente na vida do filho, cumprindo seus deveres de conviver, acompanhar, orientar e prestar assistência moral.

Assim discorreu o Senador na justificação de sua proposta: 
DEVER de acompanhar a formação dos filhos, orientá-los nos momentos mais importantes, prestar-lhes solidariedade e apoio nas situações de sofrimento e, na medida do possível, fazerem-se presentes quando o menor reclama espontaneamente a sua companhia. ${ }^{165}$

O Senador pretende, com a modificação de alguns dispositivos do ECA, estabelecer uma regra geral para tornar inequívoca a configuração do abandono afetivo/moral como conduta ilícita e, assim, orientar as decisões judicias sobre o assunto, superando a insegurança jurídica criada pelas atuais divergências.

O projeto de lei já foi aprovado pela Comissão de Constituição, Justiça e Cidadania com poucas emendas que não alteram o seu teor, e no presente momento está localizado na Comissão de Direitos Humanos e Legislação Participativa aguardando a decisão terminativa.

A outra proposição sobre o tema do abandono afetivo em discussão no Congresso Nacional é o Projeto de Lei n. 4.294 de 2008, de autoria do Deputado Carlos Bezerra (PMDB-MT), que altera o texto do Código Civil (Lei 10.406/02) e do Estatuto do Idoso (Lei 10.741/03), estabelecendo a possibilidade de indenização por dano moral em razão do abandono afetivo.

No Código Civil, o Deputado propõem que se acrescente um parágrafo no artigo $1.632^{166}$ com a seguinte redação: "Parágrafo único. O abandono afetivo sujeita os pais ao pagamento de indenização por danos morais" $" 167$.

E no Estatuto do Idoso, propõem o acréscimo de mais um parágrafo no artigo $3^{\text {o168 }}$, do seguinte modo: " $\$ 2^{\circ}$. O abandono afetivo sujeita os filhos ao pagamento de indenização por dano moral"169.

\footnotetext{
${ }^{165}$ BRASIL, Senado Federal. Projeto de Lei do Senado n. 700 de 6 de dezembro de 2007. Autoria: Senador Marcelo Crivella. Disponível em: 〈http://www6.senado.gov.br/mate-pdf/11978.pdf>. Acesso em 18 de outubro de 2012.

166 “Art. 1632. A separação judicial, o divórcio e a dissolução da união estável não alteram as relações entre pais e filhos senão quanto ao direito, que aos primeiros cabe, de terem em sua companhia os segundos."

${ }^{167}$ BRASIL, Câmara dos Deputados. Projeto de Lei n. 4.294 de 12 de novembro de 2008. Autoria: Deputado Carlos Bezerra. Disponível em: <http://www.camara.gov.br/proposicoesWeb/prop_mostrarintegra?codteor=613432\&filename=PL +4294/2008>. Acesso em 18 de outubro de 2012.

168 “Art. $3^{\circ}$. É obrigação da família, da comunidade, da sociedade e do Poder Público assegurar ao idoso, com absoluta prioridade, a efetivação do direito à vida, à saúde, à alimentação, à educação,
} 
O Deputado explica que nas obrigações entre pais e filhos, não existe somente a prestação de auxílio material, mas também há a necessidade de auxílio moral, consistente na prestação de apoio, afeto e atenção, indispensáveis ao adequado desenvolvimento da personalidade dos filhos e ao respeito às pessoas idosas.

Da mesma forma que a justificativa do projeto de lei em andamento no Senado Federal admite que o amor e o afeto não podem ser obrigados por lei, a justificativa do Deputado que propôs na Câmara também vai no mesmo sentido. Assim finalizou sua justificação: "Por sua vez, se é evidente que não se pode obrigar filhos e pais a se amar, deve-se ao menos permitir ao prejudicado o recebimento de indenização pelo dano causado."170

O projeto já foi aprovado na Comissão de Seguridade Social e Família, e no momento se encontra na Comissão de Constituição, Justiça e Cidadania.

Como pode-se notar, uma nova onda de mudanças vem acontecendo dentro do poder público no que se refere ao Direito de Família. O tema do abandono afetivo já está sendo tratado pelos Poderes Judiciário e Legislativo e já observamos a evolução que vem alcançando, isto é, está cada vez maior a possibilidade de se obter uma indenização por dano moral em virtude do abandono afetivo paterno, ou até materno.

\footnotetext{
à cultura, ao esporte, ao lazer, ao trabalho, à cidadania, à liberdade, à dignidade, ao respeito e à convivência familiar e comunitária."

${ }^{169}$ BRASIL, Câmara dos Deputados. Projeto de Lei n. 4.294 de 12 de novembro de 2008. Autoria: Deputado Carlos Bezerra. Disponível em: <http://www.camara.gov.br/proposicoesWeb/prop_mostrarintegra?codteor=613432\&filename=PL +4294/2008>. Acesso em 18 de outubro de 2012.

${ }^{170}$ BRASIL, Câmara dos Deputados. Projeto de Lei n. 4.294 de 12 de novembro de 2008. Autoria: Deputado Carlos Bezerra Disponível em: <http://www.camara.gov.br/proposicoesWeb/prop_mostrarintegra?codteor $=613432 \&$ filename $=\mathrm{PL}$ +4294/2008>. Acesso em 18 de outubro de 2012.
} 


\section{CONCLUSÃO}

A partir de apontamentos doutrinários, jurisprudenciais e legislativos, o presente trabalho teve como foco principal analisar o cabimento de indenização a título de danos morais nos casos de abandono afetivo paterno.

Primeiramente, utilizando um enfoque histórico, demonstrou-se como o Direito de Família e o próprio conceito de entidade familiar sofreram mudanças ao longo dos anos, deixando de se basear somente no patrimônio, para atentar mais às pessoas como sujeito de direitos e seus sentimentos.

Da mesma forma, analisando a evolução legislativa, pôde-se perceber como o pátrio poder sofreu modificações até atingir o atual poder familiar, passando de um direito do pai exercido exclusivamente sobre o filho, até se tornar um direito-dever de ambos os pais, que devem o exercer no interesse dos filhos. Analisou-se, então, a existência do poder familiar como um encargo legalmente atribuído aos pais, que devem criar, educar e zelar pelos aspectos materiais e morais de seus descendentes.

Contudo, mesmo que o poder familiar seja considerado um dever legal atribuído aos pais, ao analisarmos as demandas que surgem por força do abandono afetivo paterno, constatamos que muitos pais ainda se ausentam desse dever, o que leva ao grande número de crianças e adolescentes que crescem sem o amparo da figura paterna.

Por conta disso, observou-se que a ausência, o abandono e a rejeição desse pai podem, em alguns casos, acarretar sérios danos e prejuízos à formação e à personalidade de seus filhos. Isto é, a falta de cuidado e de afeto podem gerar danos psíquicos à criança, fazendo surgir pessoas com baixa auto estima, rebeldes, agressivas, tristes ou inseguras.

Por outro lado, constatou-se também que a presença de relações afetivas e de cuidado são essenciais para a criança obter um 
desenvolvimento saudável e pleno, sem trauma, depressão, dor, mágoa, ressentimento, agressão ou delinquência.

O dever de cuidar, educar, prestar assistência imaterial e estar presente na vida dos filhos é inerente ao poder familiar, ou seja, não é uma faculdade dos pais, mas sim um dever que lhes é imposto. Indo além, não só um dever, mas também é um direito dos filhos, que por sua vez, tem o direito de conviver e ser cuidado por seu pai, ainda que este não detenha a guarda.

Sendo assim, foi demonstrado que o pai que deixar de cumprir seus deveres, principalmente de cuidado e assistência moral, estará violando obrigações que lhe foram impostas, indo em sentido oposto ao que preconizam os princípios do Direito de Família e da Constituição Federal.

Ainda, ao analisar posições doutrinarias e jurisprudências, constatouse que o afeto e o cuidado vem adquirindo importante valor jurídico, como exemplo tem-se o julgamento recente da Terceira Turma do STJ que reconheceu a possibilidade de danos morais por abandono afetivo sustentando ser o cuidado dever legal imposto aos pais, como já foi amplamente discutido no presente estudo.

Então, analisou-se os pressupostos caracterizadores da responsabilidade civil subjetiva (conduta, culpa, dano e nexo causal) de forma genérica, para assim fazer uma ligação entre esses e a sua aplicação à hipótese de abandono afetivo.

O que se pretendeu demonstrar com essa ligação é que não pode haver a aplicação geral e irrestrita da responsabilidade civil em todos os casos de abandono afetivo, mas sim mostrou-se que a análise dos casos concretos deve ser feita de forma cuidadosa e atenta, observando caso a caso se estão presentes os elementos da responsabilidade civil, isto é, se houve uma conduta culposa por parte do pai e se foi esta conduta que gerou um dano no filho. 
Desse modo, foram analisadas posições jurisprudências tanto a favor dos danos morais por abandono afetivo, como contrarias a essa possibilidade.

Dentre as posições desfavoráveis, existem aquelas em que o magistrado não visualizou a ocorrência de dano ou ato ilícito por parte do genitor, o que até nos parece aceitável, visto que a presença do dano e da conduta omissiva do genitor devem ser configurados caso a caso. Entretanto, viu-se também que a maioria dos julgados desfavoráveis se utilizam do argumento de que não se pode obrigar o pai a amar ou dar carinho à um filho, e estas justificativas, por outro lado, não nos parecem aceitáveis.

Como ficou demonstrado na análise feita sobre o voto da Ministra Nancy Andrighi, no recente julgamento do STJ, não se trata mais de discutir o amor ou afeto concedido ou não pelo pai, mas sim trata-se de um dever legal de cuidado que lhe foi imposto e que deve ser cumprido.

Ainda, na análise das posições favoráveis, notou-se que estas decisões também não pretendiam fazer um pai negligente amar seu filho e começar a lhe dar carinho, já que nunca o fez. Mas, por outro lado, o que estas decisões recentes almejam é mostrar para esses pais que eles possuem um dever legal de cuidar da sua prole e, ao se omitirem dessa obrigação, suas atitudes estão erradas e poderão comprometer o caráter dessas crianças, que, frisa-se, não pediram para nascer.

Vale citar um trecho escrito por Pereira:

Se um pai ou uma mãe não quiserem dar atenção, carinho e afeto àqueles que trouxeram ao mundo, ninguém pode obrigá-los, mas à sociedade cumpre o papel solidário de lhes dizer, de alguma forma, que isso não está certo e que tal atitude pode comprometer a formação e o caráter dessas pessoas abandonadas, afetivamente."171

\footnotetext{
${ }^{171}$ PEREIRA Rodrigo da Cunha. Nem só de pão vive o Homem: Responsabilidade civil por abandono afetivo. Disponível em: <http://www.ibdfam.org.br/novosite/artigos/detalhe/392>. Acesso em 09 de outubro de 2012.
} 
Dessa forma, não se pretendeu com o presente estudo de forma alguma monetarizar o afeto ou atribuir um preço para o amor. Até porque, como foi demonstrado com os projetos legislativos no último capítulo, a ideia das propostas não é obrigar um pai a amar seu filho, isso seria impossível mesmo que por lei, mas sim o intuito é obrigá-lo a se fazer presente na vida do filho, cumprindo seus deveres de conviver, orientar, educar, cuidar e prestar assistência moral.

Com isso, adotamos posição no sentido de que é cabível uma indenização a título de danos morais nos casos de abandono afetivo, até porque esta responsabilização civil do pai visa atingir um caráter punitivo, preventivo e até pedagógico.

Primeiramente porque a criança não pediu para nascer, mas já que nasceu ambos os pais são responsáveis por este nascimento, e quando se omitem de seus deveres, devem sofrer uma sanção por esta conduta. Segundo porque esta punição vai orientar e educar esses pais a não agirem mais da mesma forma, prevenindo-se também o surgimento de novos casos iguais.

Diante disso, conclui-se com o presente estudo, que os pais podem sim ser responsabilizados pelas posturas omissivas que adotam e que geram consequências negativas no desenvolvimento de seus filhos. Nesse sentido, uma grande onda de mudanças já vem tomando conta da doutrina e da jurisprudência, e quem sabe até das leis em um futuro próximo, ao admitirem a possibilidade de indenização em danos morais quando um dos pais abandona afetivamente seu filho. 


\section{BIBLIOGRAFIA}

BERNARDO, Wesley de Oliveira Louzada. Dano moral: critérios de fixação do valor. Rio de Janeiro: Renovar, 2005. 205 p.

BRASIL, Câmara dos Deputados. Projeto de Lei n. 4.294 de 12 de novembro de 2008. Autoria: Deputado Carlos Bezerra. Disponível em: <http://www.camara.gov.br/proposicoesWeb/prop_mostrarintegra?codteor= 613432\&filename=PL+4294/2008>. Acesso em 18 de outubro de 2012.

BRASIL, Código Civil de 1916. Lei n. 3.071, de $1^{\text {o }}$ de janeiro de 1916.

BRASIL, Código Civil de 2002. Lei n. 10.406, de 10 de janeiro de 2002.

BRASIL, Constituição da Republica Federativa do Brasil de 1988.

BRASIL, Estatuto da Criança e do Adolescente. Lei n. 8.069, de 13 de julho de 1990.

BRASIL, Senado Federal. Projeto de Lei do Senado n. 700 de 6 de dezembro de 2007. Autoria: Senador Marcelo Crivella. Disponível em: <http://www6.senado.gov.br/mate-pdf/11978.pdf>. Acesso em $18 \mathrm{de}$ outubro de 2012.

CAHALI, Yussef Said. Dano moral. $3^{\mathrm{a}}$ ed. São Paulo: Revista dos Tribunais, 2005. $832 \mathrm{p}$.

CASTRO, Guilherme Couto de. Direto Civil: lições: parte geral, obrigações, responsabilidade civil, reais, família e sucessões. $4^{\mathrm{a}}$ ed. Rio de Janeiro: Impetus, 2011. 438 p.

COMARCA DE CAPÃO DA CANOA/RS, Processo n. 141/1030012032-0, Juiz Mário Romano Maggioni, Rio Grande do Sul, julgado em 15 de setembro de 2003.

DIAS, Maria Berenice. Manual de Direito das Famílias. $8^{\mathrm{a}}$ ed. São Paulo: Revista dos Tribunais, 2011. 688 p.

DIAS, Maria Berenice. O direito dos filhos a seus pais. Disponível em: $<$ http://www.mariaberenice.com.br/uploads/o_direito_dos_filhos_a_seus_p ais.pdf $>$. Acesso em 10 de outubro de 2012.

DINIZ, Maria Helena. Curso de direito civil brasileiro: responsabilidade civil. Volume 7. $17^{\mathrm{a}}$ ed. São Paulo: Saraiva, 2003. 598 p. 
FARIAS, Cristiano Chaves de; ROSENVALD, Nelson. Direito Civil: Teoria Geral. $8^{\mathrm{a}}$ ed. Rio de Janeiro: Lumen Juris, 2009. 776 p.

FILHO, Sérgio Cavalieri. Programa de responsabilidade civil. $6^{\mathrm{a}}$ ed. São Paulo: Malheiros, 2005. 584 p.

GOMES, Orlando. Direito de família. $11^{\mathrm{a}}$ ed. Rio de Janeiro: Forense, 1999. $474 \mathrm{p}$.

GONÇALVES, Carlos Roberto. Responsabilidade Civil. $9^{\text {a }}$ ed. São Paulo: Saraiva, 2005. 966 p.

HIRONAKA Giselda Maria Fernandes Novaes. Os contornos jurídicos da responsabilidade afetiva na relação entre pais e filhos - além da obrigação legal de caráter material. Disponível em: <http://www.ibdfam.org.br/novosite/artigos/detalhe/289>. Acesso em 09 de outubro de 2012.

HIRONAKA Giselda Maria Fernandes Novaes. Pressuposto, elementos e limites do dever de indenizar por abandono afetivo. In: PEREIRA, Tânia da Silva; PEREIRA, Rodrigo Cunha (Coords.). A ética da convivência familiar e sua efetividade no cotidiano dos tribunais. Rio de Janeiro: Forense, 2006. p. $131-149$.

HIRONAKA, Giselda Maria Fernandes Novaes; OLIVEIRA, Euclides de. Do Direito de Família. In: DIAS, Maria Berenice; PEREIRA, Rodrigo da Cunha (Coords.). Direito de Família e o Novo Código Civil. $4^{\mathrm{a}}$ ed. rev. e atual. Belo Horizonte: Del Rey, 2005. p. $1-7$.

LÔBO, Paulo Luiz Netto. Direito Civil: famílias. $4^{\mathrm{a}}$ ed. São Paulo: Saraiva, 2011. $437 \mathrm{p}$.

MADALENO, Rolf. Curso de Direito de Família. $4^{\mathrm{a}}$ ed. Rio de Janeiro: Forense, 2011. $1211 \mathrm{p}$.

MORAES, Maria Celina Bodin de. Danos à pessoa humana: uma leitura civil-constitucional dos danos morais. Rio de Janeiro: Renovar, 2003. 356 p.

MORAES, Maria Celina Bodin de. Danos morais em família? Conjugalidade, parentalidade e responsabilidade civil. In: PEREIRA, Tânia da Silva; PEREIRA, Rodrigo Cunha (Coords.). A ética da convivência familiar e sua efetividade no cotidiano dos tribunais. Rio de Janeiro: Forense, 2006. p. $171-202$. 
MORAES, Maria Celina Bodin. Danos morais e relações de família. In: PEREIRA, Rodrigo da Cunha (Coord.). Afeto, ética, família e o novo Código Civil brasileiro: anais do IV Congresso Brasileiro de Direito de Família. Belo Horizonte: IBDFAM, Ordem dos Advogados do Brasil, Del Rey, 2004. 685 p.

NADER, Paulo. Curso de direito civil: Direito de família. Volume 5. $2^{\mathrm{a}}$ ed. Rio de Janeiro: Forense, 2008. 569 p.

NAZARETH, Eliana Riberti. Guarda ou responsabilidade parental? Direito de visitas ou Direito à convivência?. In: PEREIRA, Tânia da Silva; PEREIRA, Rodrigo Cunha (Coords.). A ética da convivência familiar e sua efetividade no cotidiano dos tribunais. Rio de Janeiro: Forense, 2006. p. $203-213$.

NOVAES, Maria Helena. A convivência entre as gerações e o contexto sociocultural. In: PEREIRA, Tânia da Silva; PEREIRA, Rodrigo Cunha (Coords.). A ética da convivência familiar e sua efetividade no cotidiano dos tribunais. Rio de Janeiro: Forense, 2006. p. 215 - 230.

OLIVEIRA, José Sebastião de. apud VENOSA, Sílvio de Salvo. Direito civil: Direito de família. $4^{\mathrm{a}}$ ed. São Paulo: Atlas, 2004. p. 30-31.

PEREIRA Rodrigo da Cunha. Nem só de pão vive o Homem: Responsabilidade civil por abandono afetivo. Disponível em: <http://www.ibdfam.org.br/novosite/artigos/detalhe/392>. Acesso em 09 de outubro de 2012.

PEREIRA, Caio Mário da Silva. Instituições de Direito Civil: Direito de Família. 18a ed. Rio de Janeiro: Forense, 2010. 623 p.

PEREIRA, Tânia da Silvia. O cuidado como valor jurídico. In: PEREIRA, Tânia da Silva; PEREIRA, Rodrigo Cunha (Coords.). A ética da convivência familiar e sua efetividade no cotidiano dos tribunais. Rio de Janeiro: Forense, 2006. p. 231 - 256.

REIS, Clayton. Dano moral. $4^{\text {a }}$ ed. Rio de Janeiro: Forense, 1998. 145 p.

SARLET, Ingo Wolfgang. Dignidade da Pessoa Humana e Direitos Fundamentais na Constituição Federal de 1988. $4^{\mathrm{a}}$ ed. Porto Alegre: Livraria do Advogado, 2006. 158 p.

STJ, Informativo n. 0392, Período: 27 de abril a $1^{0}$ de maio de 2009, Quarta Turma. Disponível em: $<$ http://www.stj.jus.br/SCON/infojur/toc.jsp?livre=0392\&\&b=INFJ \&p=tru $\mathrm{e} \& \mathrm{t}=\mathrm{JURIDICO} \& \mathrm{l}=10 \& \mathrm{i}=21>$. Acesso em 16 de outubro de 2012. 
STJ, Recurso Especial n. 1159242/SP (2009/0193701-9), Rel. Min. Nancy Andrighi, Terceira Turma, Brasília, julgado em 24 de abril de 2012.

STJ, Recurso Especial n. 514.350/SP, Rel. Min. Aldir Passarinho Junior, Quarta Turma, Brasília, julgado em 28 de abril de 2009.

STJ, Recurso Especial n. 757-411/MG, Rel. Min. Fernando Gonçalves, Quarta Turma, Brasília, julgado em 29 de novembro de 2005.

STJ. Pai recorre de decisão sobre dano moral por abandono afetivo. Notícia retirada do site do STJ. Disponível em: <http://www.stj.jus.br/portal_stj/publicacao/engine.wsp?tmp.area=398\&tm p.texto=105957>. Acesso em 18 de outubro de 2012 .

TA/MG, Sétima Câmara Cível, Apelação Cível n. 408-550-5, Rel. Juiz Unias Silva, Belo Horizonte, julgado em 01 de abril de 2004.

TJ/RJ, Décima Primeira Câmara Cível, Apelação Cível n. 2007.001.63727, Rel. Des. José Carlos de Figueiredo, Rio de Janeiro, julgado em 9 de abril de 2008.

TJ/RJ, Décima Segunda Câmara Cível, Apelação Cível n. 015461761.2010.8.19.0001, Rel. Des. Cherubin Schwartz, Rio de Janeiro, julgado em 3 de maio de 2012.

TJ/RS, Oitava Câmara Cível, Apelação Cível n. 70021427695, Rel. Des. Claudir Fidelis Faccenda, Rio Grande do Sul, julgado em 29 de novembro de 2007.

TJ/RS, Oitava Câmara Cível, Apelação Cível n. 70044172401, Rel. Des. Luiz Felipe Brasil Santos, rio Grande do Sul, julgado em 13 de outubro de 2011.

TJ/RS, Sétima Câmara Cível, Apelação Cível n. 70019263409, Rel. Des. Luiz Felipe Brasil Santos, Rio Grande do Sul, julgado em 8 de agosto de 2007.

TJ/RS, Sétima Câmara Cível, Apelação Cível n. 70045481207, Relatora

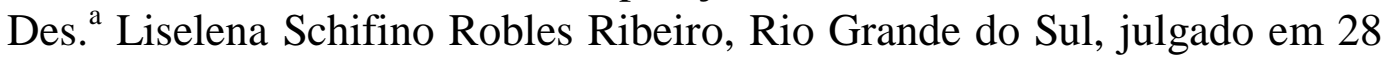
de março de 2012.

TJ/SC, Segunda Câmara de Direito Civil, Apelação Cível n. 2006.0150530, Rel. Des. Monteiro Rocha, Santa Catarina, julgado em 10 de dezembro de 2008. 
TJ/SP, $7^{\text {a }}$ Câmara "B" de Direito Privado, Apelação Cível n. 361.389.4/200, Rel. Des. ${ }^{a}$ Daise Fajardo Jacot, São Paulo, julgado em 26 de novembro de 2008.

TJ/SP, Quarta Câmara de Direito Privado, Apelação Cível n. 599506490, Rel. Des. Maia da Cunha, São Paulo, julgado em 11 de dezembro de 2008.

VENOSA, Sílvio de Salvo. Direito civil: Direito de família. $4^{\text {a }}$ ed. São Paulo: Atlas, 2004. 497 p.

VENOSA, Sílvio de Salvo. Direito Civil: Responsabilidade civil. $5^{\text {a }}$ ed. São Paulo: Atlas, 2005. 


\title{
ANEXO I
}

PROJETO DE LEI DO SENADO N. 700, de 2007

\author{
Modifica a Lei no. 8.069, de 13 de julho de 1990 \\ ("Estatuto da Criança e do Adolescente") para \\ caracterizar o abandono moral como ilícito civil e \\ penal, e dá outras providências.
}

O CONGRESSO NACIONAL decreta:

Art. $10 \mathrm{O}$ art. 4o da Lei no. 8.069, de 13 de julho de 1990, passa a vigorar acrescido dos seguintes $\S \S 20$ e 30 , renumerado o atual parágrafo único como $§ 10$ :

"Art. 40

$\S 10$.

§ 20. Compete aos pais, além de zelar pelos direitos de que trata o art. 3o desta Lei, prestar aos filhos assistência moral, seja por convívio, seja por visitação periódica, que permitam o acompanhamento da formação psicológica, moral e social da pessoa em desenvolvimento.

$\S$ 3o. Para efeitos desta Lei, compreende-se por assistência moral devida aos filhos menores de dezoito anos:

I - a orientação quanto às principais escolhas e oportunidades profissionais, educacionais e culturais;

II - a solidariedade e apoio nos momentos de intenso sofrimento ou dificuldade;

III - a presença física espontaneamente solicitada pela criança ou adolescente e possível de ser atendida.(NR)" 
Art. 2o Os arts. 5o, 22, 24, 56, 58, 129 e 130 da Lei no. 8.069, de 13 de julho de 1990, passam a vigorar com as seguintes alterações:

"Art. 5o.

Parágrafo único. Considera-se conduta ilícita, sujeita a reparação de danos, sem prejuízo de outras sanções cabíveis, a ação ou a omissão que ofenda direito fundamental de criança ou adolescente previsto nesta Lei, incluindo os casos de abandono moral. (NR)"

“Art. 22. Aos pais incumbe o dever de sustento, guarda, convivência, assistência material e moral e educação dos filhos menores, cabendolhes ainda, no interesse destes, a obrigação de cumprir e fazer cumprir as determinações judiciais (NR)."

“Art. 24. A perda e a suspensão do pátrio poder serão decretadas judicialmente, em procedimento contraditório, nos casos previstos na legislação civil, bem como na hipótese de descumprimento injustificado dos deveres e obrigações a que aludem o art. 22. (NR)"

"Art. 56. IV negligência, abuso ou abandono na forma prevista nos arts. 4o e 5o desta Lei. (NR)"

“Art. 58. No processo educacional respeitar-se-ão os valores culturais, morais, éticos, artísticos e históricos próprios do contexto social da criança e do adolescente, garantindo-se a estes a liberdade da criação e o acesso às fontes de cultura. (NR)"

“Art. 129. São medidas aplicáveis aos pais ou responsável:

Parágrafo único. Na aplicação das medidas previstas nos incisos IX 
e X deste artigo, observar-se-á o disposto nos arts. 22, 23 e 24. (NR)"

“Art. 130. Verificada a hipótese de maus-tratos, negligência, opressão ou abuso sexual impostos pelos pais ou responsável, a autoridade judiciária poderá determinar, como medida cautelar, o afastamento do agressor ou responsável da moradia comum. (NR)"

Art. 3o A Lei no. 8.069, de 13 de julho de 1990, passa a vigorar acrescida do seguinte art. 232-A:

“Art. 232-A. Deixar, sem justa causa, de prestar assistência moral ao filho menor de dezoito anos, nos termos dos $\S \S 2$ e e 30 do art. 4o desta Lei, prejudicando-lhe o desenvolvimento psicológico e social. Pena - detenção, de um a seis meses.”

Art. 4o Esta Lei entra em vigor na data de sua publicação.

\section{JUSTIFICAÇÃO}

A Lei não tem o poder de alterar a consciência dos pais, mas pode prevenir e solucionar os casos intoleráveis de negligência para com os filhos. Eis a finalidade desta proposta, e fundamenta-se na Constituição Federal, que, no seu art. 227, estabelece, entre os deveres e objetivos do Estado, juntamente com a sociedade e a família, o de assegurar a crianças e adolescentes - além do direito à vida, à saúde, à alimentação, à educação, ao lazer - o direito à dignidade e ao respeito.

Mas como conferir dignidade e respeito às crianças e adolescentes, se estes não receberem a presença acolhedora dos genitores? Se os pais não lhes transmitem segurança, senão silêncio e desdém? Podem a indiferença e 
a distância suprir as necessidades da pessoa em desenvolvimento? Pode o pai ausente - ou a mãe omissa - atender aos desejos de proximidade, de segurança e de agregação familiar reclamados pelos jovens no momento mais delicado de sua formação? São óbvias as respostas a tais questionamentos.

Ninguém está em condições de duvidar que o abandono moral por parte dos pais produz sérias e indeléveis conseqüências sobre a formação psicológica e social dos filhos.

Amor e afeto não se impõem por lei! Nossa iniciativa não tem essa pretensão. Queremos, tão-somente, esclarecer, de uma vez por todas, que os pais têm o DEVER de acompanhar a formação dos filhos, orientá-los nos momentos mais importantes, prestar-lhes solidariedade e apoio nas situações de sofrimento e, na medida do possível, fazerem-se presentes quando o menor reclama espontaneamente a sua companhia.

Algumas decisões judiciais começam a perceber que a negligência ou sumiço dos pais são condutas inaceitáveis à luz do ordenamento jurídico brasileiro. Por exemplo, o caso julgado pela juíza Simone Ramalho Novaes, da 1a Vara Cível de São Gonçalo, região metropolitana do Rio de Janeiro, que condenou um pai a indenizar seu filho, um adolescente de treze anos, por abandono afetivo. Nas palavras da ilustre magistrada, "se o pai não tem culpa por não amar o filho, a tem por negligenciá-lo. O pai deve arcar com a responsabilidade de tê-lo abandonado, por não ter cumprido com o seu dever de assistência moral, por não ter convivido com o filho, por não tê-lo educado, enfim, todos esses direitos impostos pela Lei”. E mais: "O poder familiar foi instituído visando à proteção dos filhos menores, por seus pais, na salvaguarda de seus direitos e deveres. Sendo assim, chega-se à conclusão de ser perfeitamente possível a condenação por abandono moral de filho com amparo em nossa legislação."

Por outro lado, a Quarta Turma do Superior Tribunal de Justiça não demonstrou a mesma sensibilidade, como deixa ver a ementa da seguinte decisão: "Responsabilidade civil. Abandono moral. Reparação. Danos 
morais. Impossibilidade. 1. A indenização por dano moral pressupõe a prática de ato ilícito, não rendendo ensejo à aplicabilidade da norma do art. 159 do Código Civil de 1916 o abandono afetivo, incapaz de reparação pecuniária." (Recurso Especial no. 757.411/MG, Relator Ministro Fernando Gonçalves, julgamento em 29/11/2005).

Entretanto, com o devido respeito à cultura jurídica dos eminentes magistrados que proferiram tal decisão, como conjugá-la com o comando do predito art. 227 da Constituição?

\begin{abstract}
“Art. 227. É dever da familia, da sociedade e do Estado assegurar à criança e ao adolescente, COM ABSOLUTA PRIORIDADE, o direito à vida, à saúde, à alimentação, à educação, ao lazer, à profissionalização, à cultura, à dignidade, ao respeito, à liberdade e à convivência familiar e comunitária, além de colocá-los a salvo de toda forma de negligência, discriminação, exploração, violência, crueldade e opressão.”
\end{abstract}

Ou, ainda, com o que determina o Código Civil:

Lei no. 10.406, de 10 de janeiro de 2002

Institui o Código Civil

“Art. 1.579. O divórcio não modificará os direitos dos pais em relação aos filhos.

Parágrafo único. Novo casamento de qualquer dos pais, ou de ambos, não poderá importar em restrição aos direitos e deveres previstos neste artigo.

Art. 1.632. A separação judicial, o divórcio e a dissolução da união estável não alteram as relações entre pais e filhos senão quando ao direito, que aos primeiros cabe, de terem em sua companhia os 


\section{segundos.}

Art. 1.634. Compete aos pais, quanto à pessoa dos filhos menores:

\section{II - tê-los em sua companhia e guarda;”}

Portanto, embora consideremos que a Constituição Federal de 1988, o Estatuto da Criança e do Adolescente (ECA) e o Código Civil contemplem a assistência moral, entendemos por bem estabelecer uma regra inequívoca que caracterize o abandono moral como conduta ilícita passível de reparação civil, além de repercussão penal.

Fique claro que a pensão alimentícia não esgota os deveres dos pais em relação a seus filhos. Seria uma leitura muito pobre da Constituição e do ECA. A relação entre pais e filhos não pode ser reduzida a uma dimensão monetária, de cifras. Os cuidados devidos às crianças e adolescentes compreendem atenção, presença e orientação.

É verdade que a lei assegura o poder familiar aos pais que não tenham condições materiais ideais. Mas a mesma lei não absolve a negligência e o abandono de menores, pessoas em formação de caráter, desprovidas, ainda, de completo discernimento e que não podem enfrentar, como adultos, as dificuldades da vida. Portanto, aceitam-se as limitações materiais, mas não a omissão na formação da personalidade.

Diante dessas considerações, propusemos modificações em diversos dispositivos do ECA, no sentido de aperfeiçoá-lo em suas diretrizes originais. Ao formular o tipo penal do art. 232-A, tivemos a preocupação de dar contornos objetivos ao problema, exigindo o efetivo prejuízo de ordem psicológica e social para efeito de consumação.

Lembramos que compromissos firmados por consenso internacional, e ratificados pelo Brasil, também apontam para a necessidade de aprimoramento das normas legais assecuratórias dos direitos das nossas criança e adolescentes, vejamos: 
Declaração dos Direitos da Criança

Adotada pela Assembléia das Nações Unidas de 20 de novembro de 1959 e ratificada pelo Brasil pelo Decreto no. 99.710/1990

PRINCÍPIO 20

A criança gozará proteção social e ser-lhe-ão proporcionadas oportunidade e facilidades, por lei e por outros meios, a fim de lhe facultar o desenvolvimento físico, mental, moral, espiritual e social, de forma sadia e normal e em condições de liberdade e dignidade. $\mathrm{Na}$ instituição das leis visando este objetivo levar-se- ão em conta sobretudo, os melhores interesses da criança.

\section{PRINCÍPIO Go}

Para o desenvolvimento completo e harmonioso de sua personalidade, a criança precisa de amor e compreensão. Criar-seá, sempre que possível, aos cuidados e sob a responsabilidade dos pais e, em qualquer hipótese, num ambiente de afeto e de segurança moral e material, salvo circunstâncias excepcionais, a criança da tenra idade não será apartada da mãe. (...)

\section{PRINCÍPIO 7o}

(...) Ser-lhe-á propiciada uma educação capaz de promover a sua cultura geral e capacitá-la a, em condições de iguais oportunidades, desenvolver as suas aptidões, sua capacidade de emitir juízo e seu senso de responsabilidade moral e social, e a tornar-se um membro útil da sociedade. Os melhores interesses da criança serão a diretriz a nortear os responsáveis pela sua educação e orientação; esta responsabilidade cabe, em primeiro lugar, aos pais. 
CONVENÇÃO DA ONU SOBRE OS DIREITOS DA CRIANÇA

Adotada pela Assembléia Geral das Nações Unidas em 20 de novembro de 1989 e ratificada pelo Brasil em 1990

\section{ARTIGO 9}

3. Os Estados Partes respeitarão o direito da criança que esteja separada de um ou de ambos os pais de manter regularmente relações pessoais e contato direto com ambos, a menos que isso seja contrário ao interesse maior da criança.

Assim, crendo que a presente proposição, além de estabelecer uma regra inequívoca que permita a caracterização do abandono moral como conduta ilícita, também irá orientar as decisões judiciais sobre o tema, superando o atual estágio de insegurança jurídica criado por divergências em várias dessas decisões, é que confiamos em seu acolhimento pelos nobres Congressistas, de sorte a permitir a sua rápida aprovação.

Sala das Sessões,

\section{Senador MARCELO CRIVELLA}




\section{ANEXO II}

PROJETO DE LEI N. 4.294, DE 2008

\section{(Do Sr. Carlos Bezerra)}

Acrescenta parágrafo ao artigo 1. 632 da lei ${ }^{\circ} 10.406$, de 10 de janeiro de 2002 - Código Civil e ao art. $3^{\circ} \mathrm{da}$ lei $\mathrm{n}^{\circ} 10.741$, de 1a de outubro de 2003 - Estatuto do Idoso -, de modo a estabelecer a indenização por dano moral em razão do abandono afetivo.

O Congresso Nacional decreta:

Art. 1o Acrescenta parágrafo ao artigo 1.632 da lei $\mathrm{n}^{\circ}$ 10.406, de 10 de janeiro de 2002 - Código Civil e ao art. da lei $\mathrm{n}^{\circ} 10.741$, de $1^{\mathrm{a}}$ de outubro de 2003 - Estatuto do Idoso -, de modo a estabelecer a indenização por dano moral em razão do abandono afetivo.

Art. $2^{\circ} \mathrm{O}$ artigo 1.632 da lei $\mathrm{n}^{\circ} 10.406$, de 10 de j aneiro de 2002 Código Civil - passa a vigorar acrescido do seguinte parágrafo único:

"Art. 1632

Parágrafo único: $\mathrm{O}$ abandono afetivo sujeita os pais ao pagamento de indenização por dano moral.(NR)"

Art. $3^{\circ} \mathrm{O}$ parágrafo único do art. $3^{\circ}$ da lei $\mathrm{n}^{\circ} 10.741$, de 1 a de outubro de 2003 - Estatuto do Idoso - passa a vigorar como parágrafo $1^{\circ}$, devendo ser acrescido o seguinte parágrafo $2^{\circ}$ ao artigo: 
"Art. $3^{\circ}$

$\S 1^{\circ}$

$\S 2^{\circ} \mathrm{O}$ abandono afetivo sujeita os filhos ao pagamento de indenização por dano moral."

\section{JUSTIFICAÇÃO}

O envolvimento familiar não pode ser mais apenas pautado em um parâmetro patrimonialista-individualista. Deve abranger também questões éticas que habitam, ou ao menos deveriam habitar, o consciente e inconsciente de todo ser humano.

Entre as obrigações existentes entre pais e filhos, não há apenas a prestação de auxílio material. Encontra-se também a necessidade de auxílio moral, consistente na prestação de apoio, afeto e atenção mínimas indispensáveis ao adequado desenvolvimento da personalidade dos filhos ou adequado respeito às pessoas de maior idade.

No caso dos filhos menores, o trauma decorrente do abandono afetivo parental implica marcas profundas no comportamento da criança. A espera por alguém que nunca telefona - sequer nas datas mais importantes o sentimento de rejeição e a revolta causada pela indiferença alheia provocam prejuízos profundos em sua personalidade.

No caso dos idosos, o abandono gera um sentimento de tristeza e solidão, que se reflete basicamente em deficiências funcionais e no agravamento de uma situação de isolamento social mais comum nessa fase da vida. A falta de intimidade compartilhada e a pobreza de afetos e de comunicação tendem a mudar estímulos de interação social do idoso e de seu interesse com a própria vida.

Por sua vez, se é evidente que não se pode obrigar filhos e pais a se amar, deve-se ao menos permitir ao prejudicado o recebimento de 
indenização pelo dano causado. Por todo exposto, clamo meus pares a aprovar o presente projeto de lei.

Sala das Sessões, em 12 de novembro de 2008.

Deputado CARLOS BEZERRA 